\title{
A vanished ecosystem: Sophora microphylla (Kōwhai) dominated forest recorded in mid-late Holocene rock shelters in Central Otago, New Zealand
}

\author{
Mike Pole
}

\begin{abstract}
When European settlers first arrived in Central Otago, New Zealand, in the 1850s, they found much of the region to be semi-arid, rocky, and treeless - at least partly due to fires after the arrival of Polynesians in the late thirteenth century or early fourteenth century. The condition of the vegetation rapidly deteriorated with the European introduction of grazing mammals (including sheep and rabbits), leading to a situation now, where it is difficult to understand what the 'original' vegetation was. However, rock overhangs (termed 'shelters' in this paper) accumulated dried vegetation in the prehuman mid-late Holocene. Much of this material appears to have been transported into the shelters as roosting material by the extinct giant moa birds. This record of dried vegetation, and sometimes the coprolites scattered through it, is therefore an important source of information about the pre-human vegetation, as well as the diet of the moa.

The present study analyses samples of mid-late Holocene dried leaf material from 115 rock shelters, identifying the taxa on the basis of epidermal details of the leaf cuticle. Based on it being the only large tree in the area now, and the nearly ubiquitous presence of its leaves in the shelters, the most important plant in the area is considered to have been Sophora microphylla. Based on the size of old, relict, 'champion', trees in the area now, it likely formed a forest with a continuous, but low (perhaps $14 \mathrm{~m}$ ) and open canopy over the study area. Other trees which were present and are entirely absent (or almost so) from the area now include Pittosporum tenuifolium and Pseudopanax ferox. They suggest more closed canopy forest, perhaps in more localized areas, but were subordinate to Sophora. However, other common plants included Carmichaelia, Rubus, and Hebe lycopodioides that are more suggestive of lower, open vegetation. There is no indication of a conifer component or of 'wetter' forest trees such as Nothofagus and Griselinia.

Cuticle within the largest associated coprolites indicate that moa (Aves, Dinornithiformes) was ingesting a similar range of plants as the shelter material. Of particular interest is that moa clearly ate Sophora microphylla, the first evidence for this. Together these data suggest a Central Otago ecosystem where a low Sophora microphylla forest predominated and was utilized and perhaps maintained by moa.
\end{abstract}

Pole, Mike. 2022. A vanished ecosystem: Sophora microphylla (Kōwhai) dominated forest recorded in mid-late Holocene rock shelters in Central Otago, New Zealand. Palaeontologia Electronica, 25(1):a1. https://doi.org/10.26879/1169 palaeo-electronica.org/content/2022/3503-vanished-ecosystem 
Mike Pole. Queensland Herbarium, Brisbane Botanic Gardens Mt Coot-tha, Mt Coot-tha Rd, Toowong, Australia murihiku@yahoo.com

Keywords: cuticle; moa; Holocene; Dinornithiformes; Sophora

Submission: 28 May 2021. Acceptance: 4 November 2021.

\section{INTRODUCTION}

The central part of the South Island, New Zealand (Central Otago), includes mountain ranges extending to over $1600 \mathrm{~m}$ above sea level that are separated by intermontane valleys around $200-400$ $\mathrm{m}$ above sea level. These lower areas are some of the driest, hottest, and coldest parts of the country. In Alexandra for example, annual rainfall can be below $400 \mathrm{~mm}$, a summer temperature of $38.7^{\circ} \mathrm{C}$ has been recorded, and a winter temperature of $11.7^{\circ} \mathrm{C}$ (Macara, 2015). When the first Europeans arrived in the mid nineteenth century it was a virtually treeless rocky, grassland-shrubland. Today, over much of the lowland in this area, native vegetation is virtually non-existent. Where not transformed outright by agriculture, native vegetation has been replaced by introduced plant species such as Thymus vulgaris, or Rosa rubiginosa (Walker et al., 2004a) and devastated by introduced mammals such as rabbits. Native plants typically remain as patches of 'grey scrub' (Wardle, 1991), including matagouri (Discaria toumatou), native brooms (Carmichaelia spp.), Coprosma, and some grasses. In some places there are stands of low Kunzea. Sophora microphylla (kōwhai) is often the only large native tree left, and these are typically isolated individuals, or small clusters, restricted to rocky fire-protected sites. In higher altitude regions (e.g., above about $570 \mathrm{~m}$ above sea level), highly relictual occurrences of other trees, such as Podocarpus, are restricted to rocky mountain gorges or fire-protected rocky outcrops (Wells, 1972).

However, explorers in the mid nineteenth century found charred logs scattered through the tussock grassland of the mountain slopes. The first comprehensive study of sub fossil wood and charcoal from the region was that of Molloy et al. (1963). The unbranched nature of the burnt Podocarpus logs suggested they grew as part of a continuous canopy, but their scattered distribution suggested that much of the canopy may have been formed by species with less durable wood, perhaps Nothofagus (note the proposal by Heenan and Smissen, 2013, to split Nothofagus into four gen- era. For simplicity, this is not followed here, but under that scheme 'Nothofagus' as used here, includes both Fuscospora and Lophozonia). Subsequent research on living vegetation documented extant patches of Kunzea (Burrell, 1965) and relictual Podocarpus (Wells, 1972). The next advances in understanding the vegetation history were made with palynology. Clark et al. (1996) concluded that late Holocene vegetation was mainly a smallleaved shrubland (with important Coprosma and Muehlenbeckia), but also with small stands of open woodland (including Sophora, Plagianthus, and probably Kunzea) and, based on "substantial" amounts of podocarp pollen (up to c. 20\%), patches of tall podocarp forest (with Prumnopitys taxifolia, P. ferruginea, Dacrycarpus dacrydioides, Podocarpus, and perhaps Dacrydium cupressinum) may have existed. A later palynological study (McGlone and Moar, 1998) also concluded that late Holocene vegetation was dominated by shrublands. However, much of the conifer pollen was interpreted as coming from stands at some distance - either from higher altitudes or even blowing from coastal lowlands.

A comprehensive review of Quaternary vertebrates from the region (Worthy, 1998) documented many taxa (mostly birds), which are today typically inhabitants of forest or at least of dense shrubland. A detailed appraisal of the relictual forests and soil charcoal record of the upper Clutha region was also an important contribution (Wardle 2001a, 2001b), although it is peripheral to the present study area. Modeling approaches have predicted a potential pre-human Central Otago vegetation in which Sophora, was important, especially in the drier areas, and perhaps Kunzea and Leptospermum as well (Walker et al., 2003, 2004b), or where Sophora was just one of several shrubs and trees Rogers et al., 2005; Leathwick et al., 2012). Other models have predicted broad conifer dominance (Hall and McGlone, 2006; McGlone et al., 2017).

Another branch of research has focused on the evidence of plant macrofossils. By its nature, the dominant rock in the area, schist, weathers easily and irregularly, and it tends to form overhangs. If the overhang is large enough and rainwa- 
ter is not funneled inwards, the interior remains very dry, and any organic material desiccates and builds up. Larger overhangs were co-opted into houses by gold miners starting in the 1860 s, while the smaller ones provided shelter for introduced animals such as sheep, goats, and rabbits. The first sheep in the area came with the earliest European settlers in the late 1850 s, and by the 1870 s, sheep, rabbits, and goats were widespread. The activities of these animals have often resulted in a compact surficial layer of droppings on the floors of the overhangs. Material lying below this datum of introduced animal droppings evidently dates to preEuropean times and radiocarbon dates confirm that most material is mid-late Holocene (Wood et al., 2008), and sometimes early Holocene (McGlone and Wood, 2019).

Based on leaf macrofossils, wood and seeds from these locations, Wood and Walker (2008, p. 250) inferred a late Holocene vegetation of "Coprosma-Olearia-Corokia shrubland with interspersed taller broadleaf-podocarp forest". Since then, research has focused on coprolites in the overhangs, and their content of seeds, pollen, and leaf remains. DNA has confirmed that some coprolites were produced by the extinct 'moa' (Aves, Dinornithiformes). These were large (some over 3 $\mathrm{m}$ tall), flightless, now extinct, herbivorous birds (Worthy and Holdaway, 2002). The coprolites indicate what the birds were eating (Wood et al., 2020) and provide a further window to the nature of the local vegetation.

The present study began in the late 1970s when I started to collect moa bones uncovered by the construction of a hydro-electric dam at Clyde (from the region that would be flooded by HydroLake Dunstan) and when searching for the 'Earnscleugh Cave' in the Conroys Catchment near Alexandra. In the early 1980s I started a University of Otago project to try and develop a stratigraphic and geomorphological framework for the QuaternaryHolocene of the Cromwell Gorge. The rock overhangs were a component of this, and Neville Ritchie, archaeologist for the Clutha Dam project, was taken to one to see what were, at that time, generally recognised to be moa coprolites. This study was postponed concentrating on the Cenozoic paleobotany of locations that would also be flooded by Lake Dunstan. I went back to Holocene work in the early 1990s and began systematically searching for appropriate overhangs and sampling the buried vegetation horizons. The discovery in 2000 of a lens of intact Pittosporum tenuifolium leaves in the Roxburgh Gorge had a profound impact on me, bringing home just how vastly different mid-late Holocene, pre-human vegetation must have been (There are no living specimens of this species within about $50 \mathrm{~km}$ ).

The aim of this study is to build on the Wood and Walker (2008) results by incorporating a much larger dataset from mid-late Holocene sites along the Kawarau-Cromwell-Roxburgh Gorges in Central Otago, but also incorporating the epidermal morphology of leaf cuticle. Utilizing cuticle allows ready identification of leaf fragments to generic level, and perhaps species level, even from small (a millimeter or two) fragments, which would not be possible from simple dried fragments.

\section{METHODS}

Within Central Otago, this study targeted three broad 'regions', the Kawarau, Cromwell, and upper Roxburgh Gorges (Figure 1), further divided into 'sectors', where rock overhangs were located by surveying on foot. In this paper, the overhangs that contain a distinct horizon of dry vegetation are referred to as 'shelters'. Those shelters with obvious human habitation or modification were avoided (apart from potential disruption to stratigraphy, these are protected under Historic Places legislation). Shelters were given consecutive numbers in order of discovery (Figures 2, 3, 4; Details in Appendix 1). Their location coordinates are given as New Zealand Transverse Mercator (NZTM), using GPS (on return visits for earlier sampled shelters).

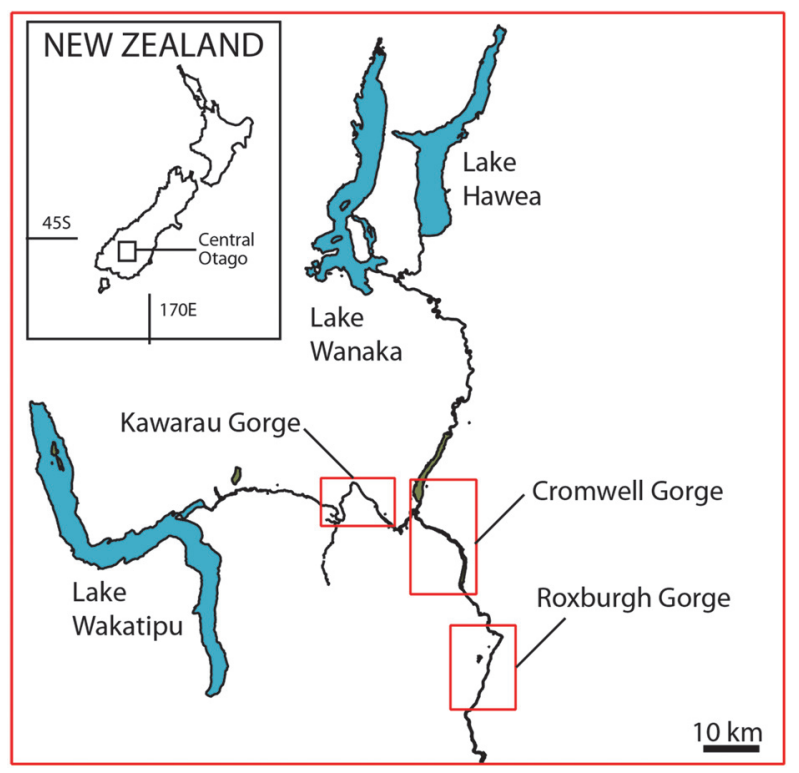

FIGURE 1. General location, indicating Central Otago in New Zealand and the three 'regions' that were studied. 


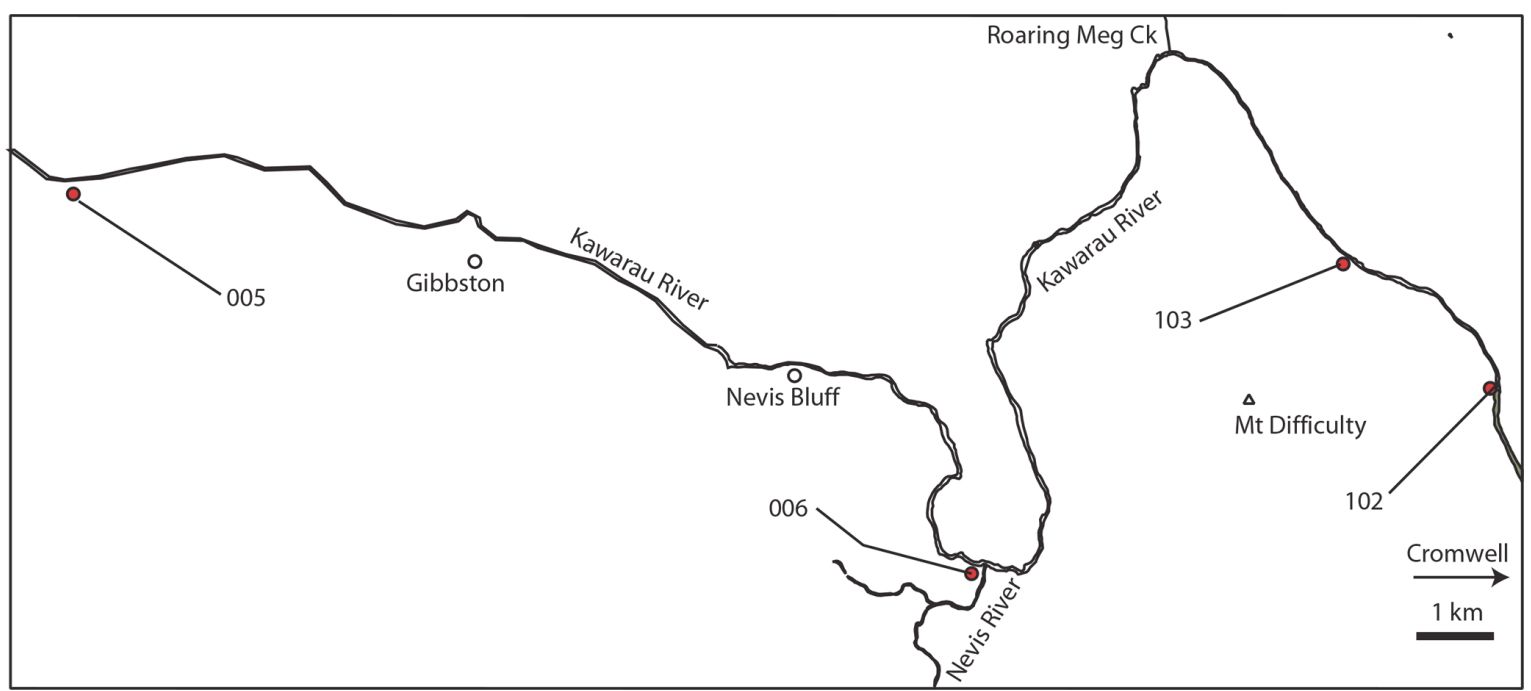

FIGURE 2. The Kawarau Region, showing shelter locations (red dots) along the Kawarau River.

As documented by Wood and Walker (2008) promising shelters generally had an upper zone of abundant sheep and rabbit droppings, which has accumulated since the start of the European era (from the late 1850s). Below this was typically a buff-brown zone of silty sand, which was generally about $5-20 \mathrm{~cm}$ thick, and included common dried plant fragments, as well as coprolites, feathers, and insects. With a few exceptions, deeper sediment was generally sterile. Using a trowel, about $300 \mathrm{~g}$ of the vegetation-rich material (sometimes including coprolites) was sampled, either directly from the side, where it was exposed by rabbit burrowing, or by digging a $10-15 \mathrm{~cm}$ hole down through to this zone with a trowel. The samples are an average over the entire vegetation-rich zone and include both vegetation and coprolites.

Bulk samples were first scanned under reflected light with a binocular microscope and relatively large specimens picked out with tweezers. However, useful identification of highly fragmented leaf material is not feasible based on simple dried material. But when reduced to cuticle and stained, even very small fragments (sub-millimetre) can be readily identified under a microscope, often to generic, or even species level. To do this, a subsample was submerged in hot water and hydrogen peroxide, then the sediment fraction sieved out, and finally 'stewed' in concentrated peroxide until leaf fragments were reduced to clear cuticle. The cuticle was then stained in safranin, and scanned under a binocular microscope with transmitted light. With this method, thousands of cuticle fragments could be scanned. The rarer taxa, and/or those represented only by particularly small frag- ments, generally stand out among the mass of more common cuticle. Searching went on until no new taxa were located. That is, the main objective was to maximize the species list for each sample.

Quantification of individual samples was not attempted on the grounds that it would be unrealistic. It would require an accurate measure of the cuticle area represented by each taxon - taxa represented by fragments of flat leaves, scales, and stems, many that would need to be mounted on microscope slides to identify, by cuticle that is mostly folded or rolled up, and would need to be individually opened out and flattened on a microscope slide, adaxial and abaxial cuticle differentiated for thousands of specimens and some account made between inherently sparse accumulations versus richer ones. At the end of this process, the value of the 'quantification', at least in terms of reconstructing vegetation, would be far from clear. It would likely represent moa choice and random variation as much as relative abundance in the surrounding vegetation. In this study, the shelters themselves are seen as the effective sampling 'devices', the level of quantification is the shelter, and frequency of a taxon throughout the shelters is regarded as a broad reflection of its prominence across the landscape.

Individual cuticle fragments (at least one of each taxon per sample) were removed with tweezers and mounted in glycerine jelly on microscope slides (these are numbers with the prefixes 'SL' and ' $L X$ ' which will give unique searching strings). Cuticle was identified based on the author's microscope slide reference collection of extant New Zealand plants (specimens prefixed with ' $\mathrm{OPH}$ '). The 


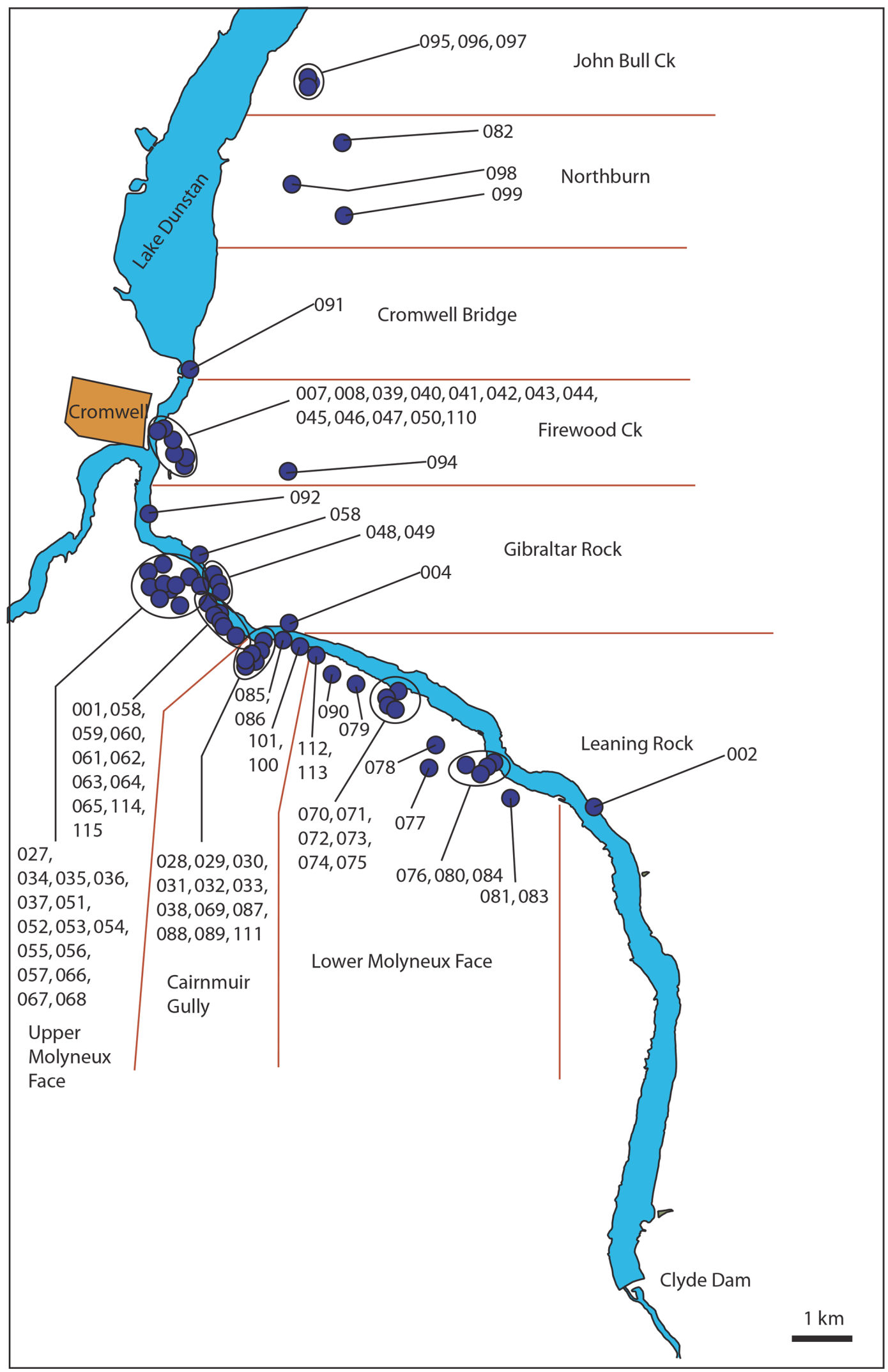

FIGURE 3. The Cromwell Region, showing shelter locations (blue dots) to the east of Lake Dunstan and within the Cromwell Gorge. Groups of closely spaced shelters are surrounded by an ellipse. Groups of closely spaced shelters are surrounded by an ellipse. Lines indicate the 'sectors'. 


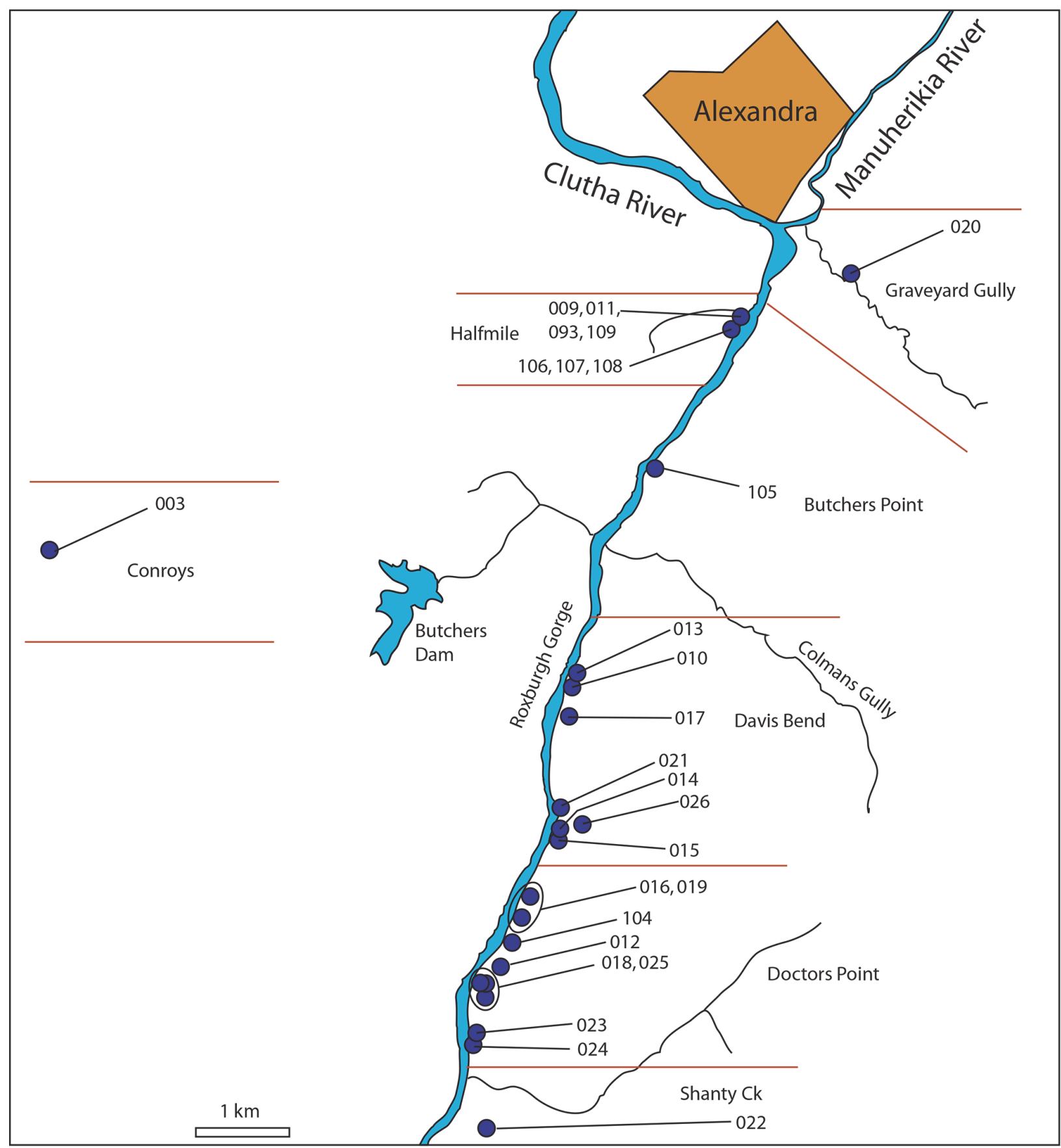

FIGURE 4. The Roxburgh Region, showing shelter locations (blue dots) centered on the Roxburgh Gorge. Groups of closely spaced shelters are surrounded by an ellipse. Lines indicate the 'sectors'.

taxonomic results are presented following the family order in APG IV (Angiosperm Phylogeny Group, 2016) with descriptive terminology of cuticle following Dilcher (1974). The species located in each shelter are given in Appendix 2.

Coprolites were also sampled for leaf cuticle, to determine what plants had been ingested. Moa coprolites are now well-established from Central
Otago rock shelters. Their size, common association with moa feathers, and 'sheared twigs' scattered through the dry vegetation layers of shelters, as well as the abundance of moa bones across the broader landscape, led to a general understanding that they belonged to moa (Worthy, 1998; Worthy and Holdaway, 2002; Wood, 2008). Since then, direct DNA evidence has confirmed the identity 
(Wood et al., 2008; Wood and Wilmshurst, 2013, 2014; Boast et al., 2018). The research has also clarified that the coprolites come in a range of sizes and morphology, and as Wood and Wilmshurst (2014) emphasised, coprolites of other taxa can be present. Disregarding ones with highly distinctive shapes, the most likely overlap in terms of size and surface morphology in Central Otago, is with the kakapo, Strigops habroptilus. Wood and Wilmshurst (2014, fig. 3) plotted coprolite length versus width for a range of genetically confirmed moa coprolites, as well as one kakapo, and also a range of 'putative' kakapo coprolites. Although most kakapo coprolites are less than $40 \mathrm{~mm}$ in any dimension (see also Horrocks et al., 2008), a few exceed this in length.

In the present study, coprolites well outside the length-width range of outlier 'putative' kakapo, are considered moa beyond any reasonable doubt (see more under Results). Coprolites were sampled by first examining them for obviously adhering material under binocular microscope. On shorter or smaller specimens, one end was sampled by being sawn off using a hack saw. On more elongate specimens, an approximately $10 \mathrm{~mm}$ wide disk was removed from the center (the remainder were archived), and the outer $2 \mathrm{~mm}$ was removed by hand-sanding. This process was to minimize any chance that cuticle fragments found after processing the coprolites were not contamination on the outside (i.e., vegetative material that became embedded in the coprolite when it was dropped on the dry shelter floor). The coprolite samples were then processed in the same way as bulk samples. The vast bulk of what remains after this processing is woody fibres. However, rare, typically very small (sub-millimetre) leaf cuticles are present among this mass. Details presented in Appendix 3.

Numbered material (including microscope slides and the remaining, unprocessed portions of coprolites) is deposited in the Otago Museum.

\section{RESULTS}

The study located 115 rock shelters that are considered to have a pre-European vegetation stratigraphic record (Figures 5 and 6). Almost all shelters lie between 200-400 $\mathrm{m}$ above sea level. Of these, three only contained fragments of moa eggshell, and another three contained only coprolites. The remaining 109 produced workable plant cuticle or leaf fragments after preparation and are used in the presence-figures below. From these, a total of 16 plant taxa could be distinguished and mostly identified to generic or species level (Figures 7-22).
These are listed below along with the more useful criteria used to recognize them. Details of their location are given in Appendix 1, and their composition in Appendix 2. Details of the coprolites (Figure 23) and their content are given in Appendix 3.

\section{Systematics of Dried Vegetation}

\author{
Family POACEAE Banhart, 1895 \\ Genus indet. \\ Figure 7
}

Material. Present in $36 \%$ of the shelters with dry vegetation. Shelter-002: LX3343; Shelter-003: LX5417; Shelter-004: LX2636, LX2637, LX2639; Shelter-005: LX5398; Shelter-006: LX5554, LX5562, LX5564, LX5566; Shelter-008: SL6667; Shelter-009: LX3227, LX3229; Shelter-010: LX3184; Shelter-011: LX3232, LX3233, LX3235, SL6702; Shelter-012: LX3144, SL6717; Shelter015: SL6700, SL6701; Shelter-016: SL6691, SL6693; Shelter-021: LX3151; Shelter-023: SL6611; Shelter-026: SL6708, SL6710; Shelter028: LX2939; Shelter-029: LX5804; Shelter-030: LX2969; Shelter-032: LX2981; Shelter-035: LX2965; Shelter-040: LX3251; Shelter-042: LX2602, LX2603; Shelter-048: LX3326; Shelter052: SL6535; Shelter-054: LX3298; Shelter-058: SL6483; Shelter-059: SL6451, SL6459; Shelter064: SL6506; Shelter-068: SL6478; Shelter-070: LX2607; Shelter-078: SL6470, SL6475; Shelter080: LX2533; Shelter-089: LX3355; Shelter-093: LX3302; Shelter-102: LX2529; Shelter-105: LX3139, LX3140; Shelter-106: LX5622; Shelter108: LX3223, LX3224; Shelter-109: LX3239; Shelter-115: LX5672, LX5673.

Remarks. Typical grass epidermis exhibits distinctive long and short epidermal cells, which occur in rows (e.g., Metcalfe, 1960; Wooller et al., 2000; Wooller, 2002). Zones of dense trichomes are sometimes present. Further identification is beyond the scope of this study and is not attempted.

\section{Family FABACEAE Lindley, 1836 \\ Genus CARMICHAELIA Brown, 1825 \\ Carmichaelia sp.}

Figure 8

Material. Present in $34 \%$ of the shelters with dry vegetation. SL6583; Shelter-002: LX3335, LX3336; Shelter-005: LX5394, LX5408; Shelter-008: SL6664; Shelter-010: LX3186; Shelter-011: LX3234; Shelter-012: LX3145; Shelter-014: SL6630; Shelter-015: SL6697; Shelter-016: SL6694; Shelter-017: LX3170; Shelter-019: LX3011; Shelter-021: LX3150; Shelter-022: SL6597, SL6598; Shelter-025: SL6678; Shelter- 

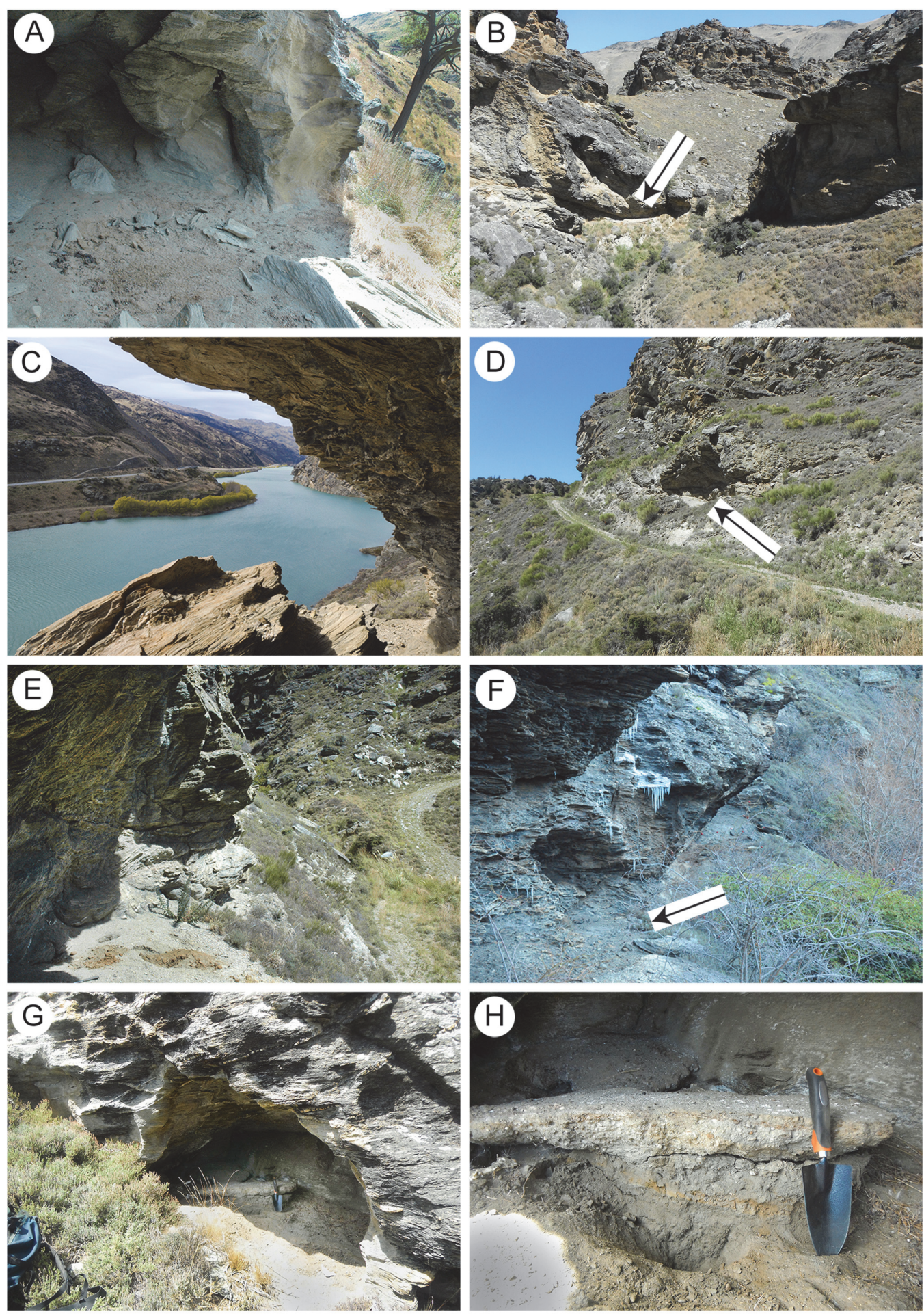

FIGURE 5. Examples of shelters the Cromwell Region. A. Shelter-29. Note relict Sophora microphylla tree (c. $350 \mathrm{~mm}$ diameter) outside. B. Shelter-71 (arrowed). This picture encapsulates the typical rocky and treeless environment of the Gorges today - and how the record of the rock shelters represents tiny windows into the very different vegetation of the past. C. Shelter-58, view from within the shelter, out over Lake Dunstan in the Cromwell Gorge. D. Shelter-69 (arrowed) above the vehicle track. E. Shelter-31. Vehicle track in the background. F. Shelter-43 (arrowed). Longest icicles are about $400 \mathrm{~mm}$. G. Shelter-83. Trowel $(260 \mathrm{~mm})$ for scale. H. Shelter-83, internal view to show 'piedmont' of remaining sediment. Grey and brown mid-late Holocene material is overlain by a post-European cap of light material with rabbit and sheep coprolites. Trowel $(260 \mathrm{~mm})$ for scale. 

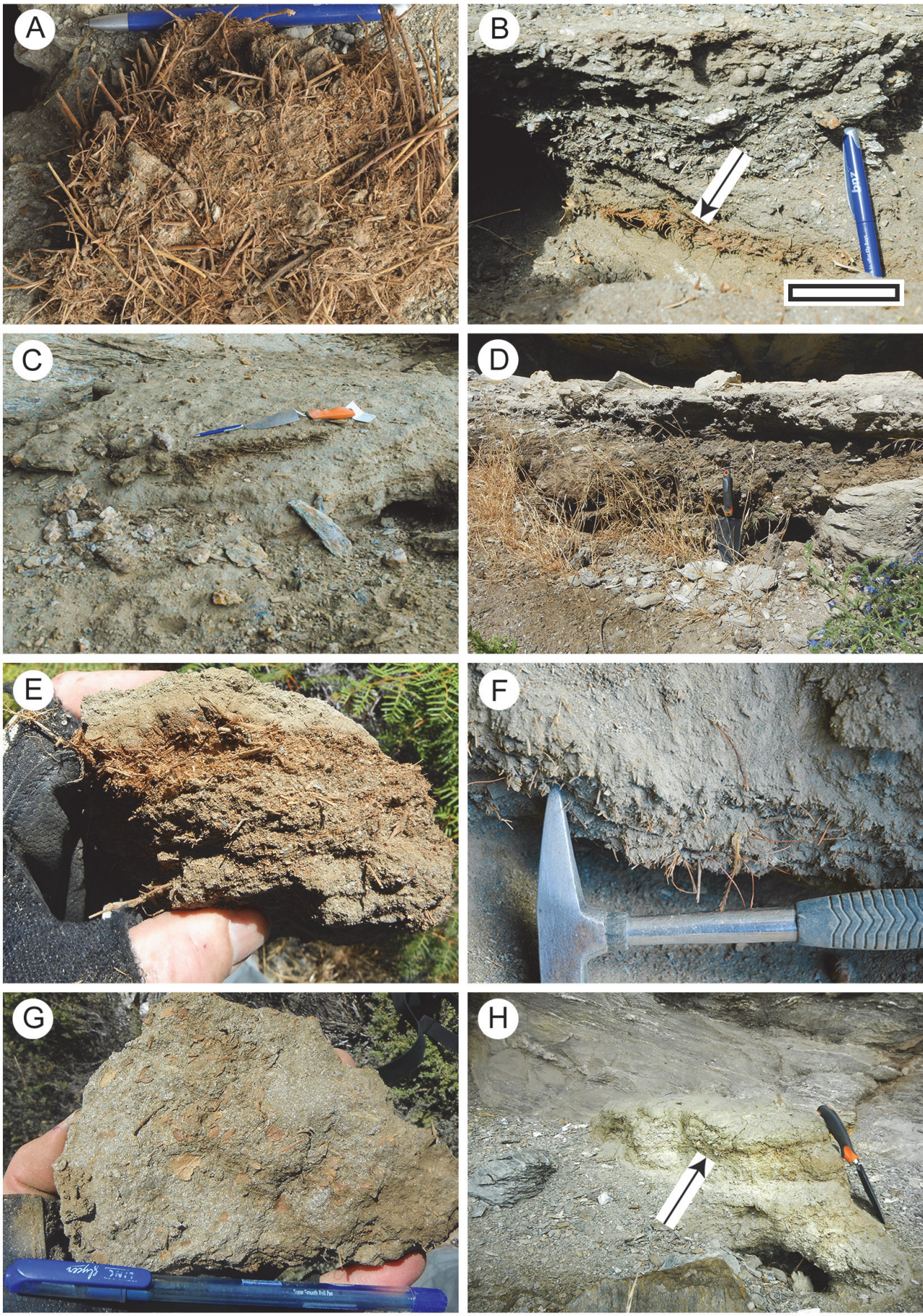

FIGURE 6. Examples of the dried vegetation zone in Cromwell Region shelters. A. Shelter-41. Surface view of an extracted mass of chewed twigs and leaf fragments. Ballpoint pen $(140 \mathrm{~mm})$ for scale. B. Shelter-40. Cross section showing a brown zone of dry vegetation (arrowed) below a grey zone of lithic rubble and capped by a zone within which sheep and rabbit coprolites are prominent. Ballpoint pen $(140 \mathrm{~mm})$ for scale. C. Shelter-46. Lens of twigs and leaf material below ballpoint pen $(140 \mathrm{~mm})$ and trowel, exposed in the face of a relict 'piedmont' of sediment. D. Shelter-71. A relatively thick brown, vegetation-rich zone adjacent trowel, capped by a pale lithic rubble. This is a close up of the floor of the shelter in Figure 5B. Trowel $(260 \mathrm{~mm})$ for scale. E. Shelter-78. Cross-section of an extracted lump of fine twigs and leaf material. Hand for scale. F. Shelter-28. Cross section of a sand-rich zone of dry vegetation and moa feathers. Rock hammer (handle $35 \mathrm{~mm}$ wide) for scale. G. Shelter-83. Surface view of extracted block of silt-rich sediment, with dried leaves on the partings. Ballpoint pen $(140 \mathrm{~mm})$ for scale. $\mathrm{H}$. Shelter-88. Small relict 'piedmont' of sediment to left of trowel $(260 \mathrm{~mm})$, with brown zone of dry vegetation (arrowed). 

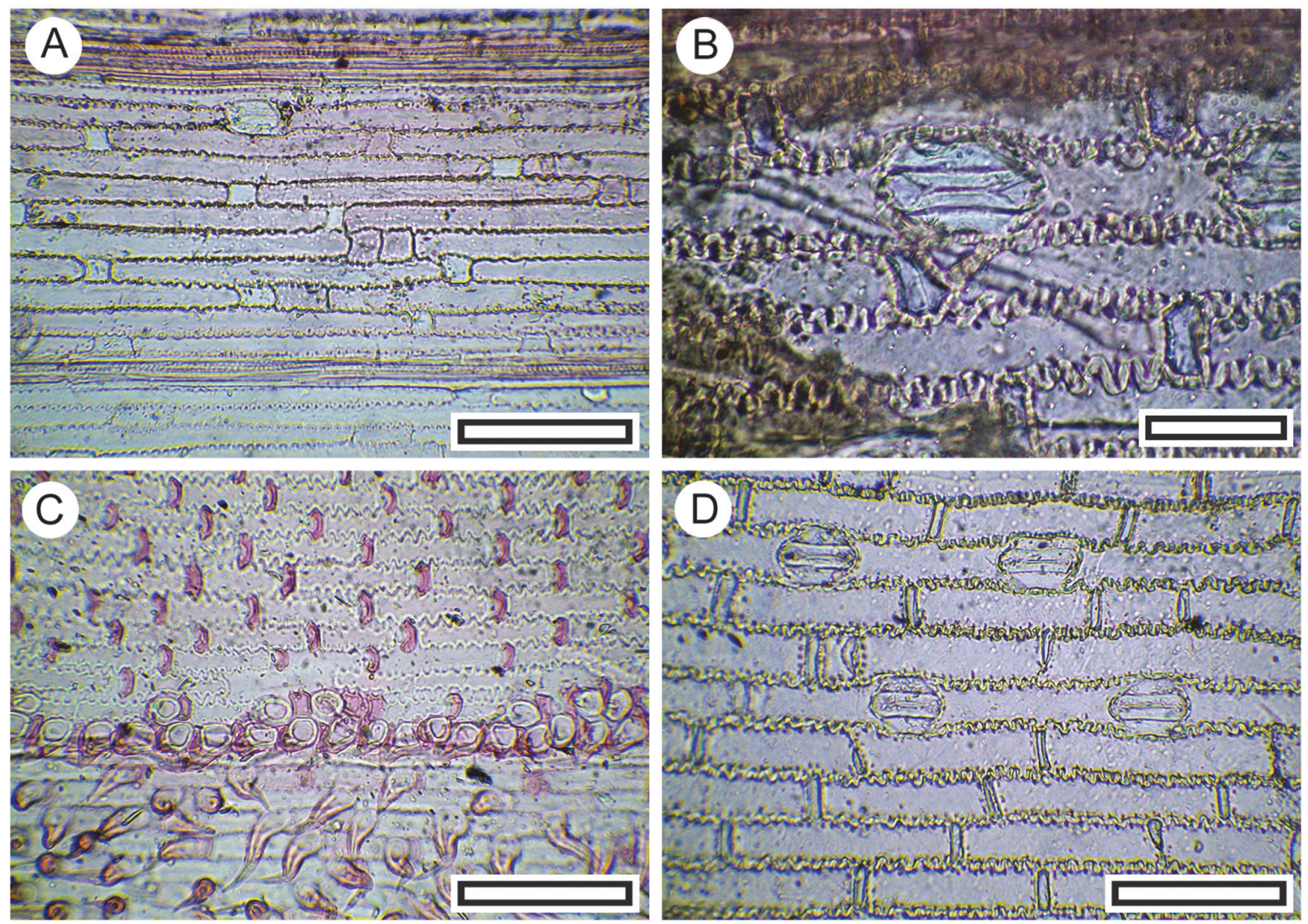

FIGURE 7. Poaceae cuticle morphology (Transmitted light microscopy). A. Showing characteristic long and short epidermal cells, and an (arrowed) stomatal complex (LX2529, Shelter-102, scale bar equals $100 \mu \mathrm{m}$ ). B. Detail, including a stomatal complex (LX2533, Shelter-80, scale bar equals $40 \mu \mathrm{m})$. C. A zone of long and short epidermal cells above, and a zone of epidermal cells with trichomes below (LX3184, Shelter-10, scale bar equals $100 \mu \mathrm{m}$ ). D. Two zone of long and short epidermal cells with a zone of purely long cells between (LX3224, Shelter-108, scale bar equals 100 $\mu \mathrm{m})$.
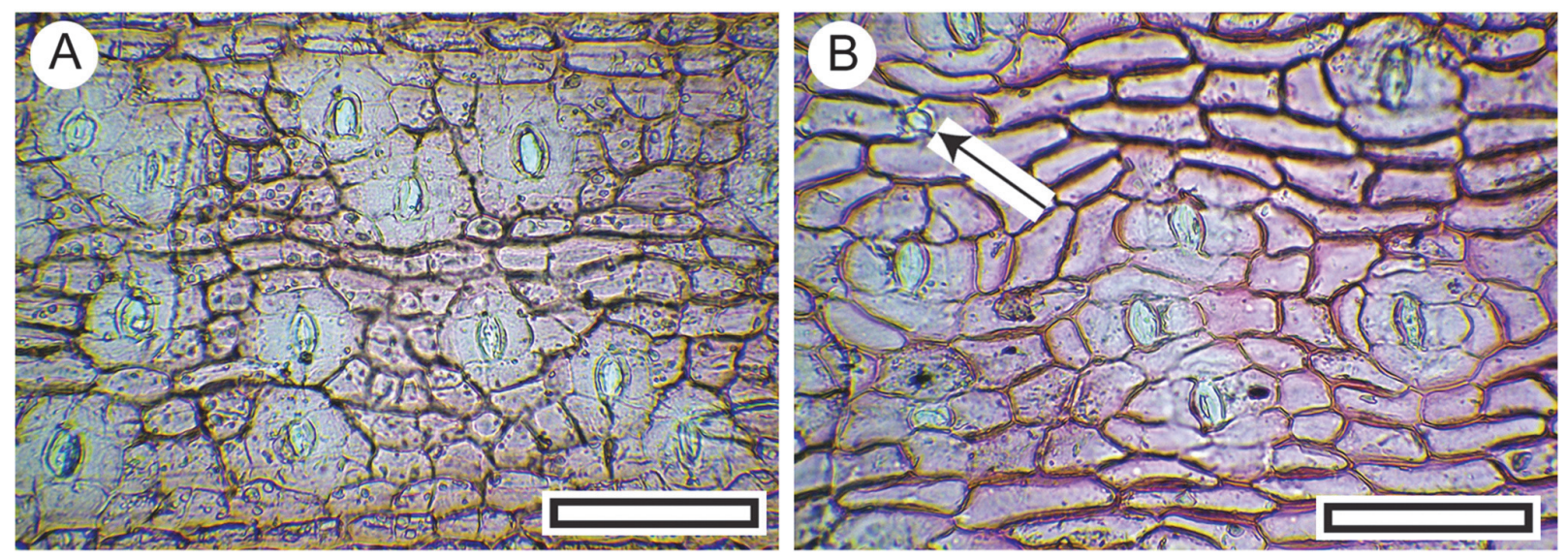

FIGURE 8. Carmichaelia sp. cuticle morphology (Transmitted light microscopy). A. Showing transversely oriented stomatal complexes along the stem (long-axis of the stem is left-right) (LX2570, Shelter-46, scale bar equals $100 \mu \mathrm{m})$. B. Also with transversely oriented stomatal complexes, but including trichome attachment (arrowed, SL6583, LX2478, Coprolite-11, scale bar equals $100 \mu \mathrm{m})$. 
029: LX5805; Shelter-030: LX2444, LX2968; Shelter-038: LX2979: LX2980; Shelter-039: LX3104; Shelter-040: LX3248; Shelter-041: SL6488, SL6489, SL6490; Shelter-046: LX2564, LX2570, LX2578; Shelter-050: LX2588; Shelter-058: SL6482; Shelter-059: SL6452; Shelter-060: LX3296; Shelter-062: LX3255; Shelter-065: LX3262; Shelter-066: SL6466; Shelter-069: SL6503, SL6515, SL6516, SL6517, SL6519; Shelter-070: LX2610; Shelter-073: SL6514; Shelter077: LX2551; Shelter-081: LX3361; Shelter-082: LX2436; Shelter-084: LX2559; Shelter-094: LX2882, LX3003; Shelter-110: LX3107, LX3108; Shelter-115: LX5674, LX5675.

Remarks. The stem cuticle of these nearly leafless 'brooms' is highly distinctive as the stomatal complexes are transversely-oriented (Pole, 2019). Heenan (1998) recognized 23 species of Carmichaelia currently indigenous to New Zealand. Several of these occur in or near the study region today, and probably more than one species is represented in the shelter material. However, the extant species display considerable plasticity in cuticle morphology, and currently the species cannot be consistently distinguished on that basis.

\section{Genus SOPHORA Linnaeus, 1753}

Sophora microphylla (Aiton, 1789)

Figure 9

Material. Present in $75 \%$ of the shelters with dry vegetation. Shelter-001: LX2714; Shelter-001: LX2716; Shelter-003: LX5416, LX5420, LX5422; Shelter-005: LX5399, LX5401, LX5407, LX5552; Shelter-006: LX5553, LX5557, LX5558, LX5565; Shelter-007: SL6599; Shelter-008: SL6668; Shelter-009: LX3225, LX3226; Shelter-012: LX3141, SL6715; Shelter-014: LX3168, SL6628, SL6629; Shelter-017: SL6578, SL6602, SL6603, SL6619; Shelter-018: LX3008, LX3018; Shelter-020: LX2954; Shelter-021: LX3148, SL6711; Shelter022: LX3353; Shelter-024: SL6605, SL6606, SL6607; Shelter-025: LX3178, SL6676, SL6679; Shelter-026: SL6709; Shelter-027: LX2973, SL6461, SL6463; Shelter-028: LX2940; Shelter029: LX5798; Shelter-030: LX2473, LX2966; Shelter-031: LX2953, LX5500, LX5501; Shelter-032: LX2915, LX2916, LX2986; Shelter-033: LX2949, LX5494, LX5495, LX5496, LX5497; Shelter-034: LX2963; Shelter-036: LX2977; Shelter-037: LX2942; Shelter-038: LX2978; Shelter-039: LX5571; Shelter-040: LX3249; Shelter-041: SL6487; Shelter-042: LX2604; Shelter-043: LX2597; Shelter-046: LX2566, LX2573; Shelter047: LX3277, LX3279; Shelter-049: LX3332; Shelter-050: LX2590; Shelter-053: LX3286; Shelter-
054: LX3284; Shelter-055: LX3316; Shelter-057: LX2531; Shelter-058: SL6484; Shelter-059: SL6455, SL6456; Shelter-060: LX3295; Shelter061: LX3301; Shelter-062: LX3274; Shelter-063: SL6529; Shelter-065: LX3261, LX3312; Shelter067: LX3258; Shelter-068: SL6501; Shelter-070: LX2608, LX2612; Shelter-071: SL6436; Shelter073: SL6511; Shelter-074: LX2539; Shelter-075: LX2595; Shelter-076: LX3006; Shelter-077: LX2550, LX2554; Shelter-078: LX3358, LX3359; Shelter-079: LX5865, LX5866, LX5667; Shelter082: LX2439, LX2449, LX2451, LX2896; Shelter086: LX3300; Shelter-087: LX3306, LX3309; Shelter-088: LX3318; Shelter-089: LX3354, LX3356; Shelter-090: LX3266; Shelter-091: LX3013; Shelter-092: LX2893, LX3002; Shelter-095: LX2889; Shelter-096: LX2880; Shelter-097: LX2461; Shelter-098: LX3022; Shelter-099: LX3028; Shelter100: LX2897, LX2900, LX2904; Shelter-101: LX2906, LX2909, LX2911; Shelter-102: LX2523; Shelter-103: LX2517, LX2518; Shelter-105: LX3138; Shelter-106: LX5623, LX5624, LX5625; Shelter-110: LX3109; Shelter-111: LX5505; Shelter-113: LX5521; Shelter-114: LX5851, LX5852, LX5853, LX5854, LX5855, LX5856, LX5859, LX5860; Shelter-115: LX5671.

Remarks. The cuticle of both adaxial and abaxial epidermal surfaces is easily recognizable. The abaxial has persistent, deeply staining trichomes, as well as subdued but numerous papilae, and relatively small, poorly staining stomata. The adaxial has simple, deeply staining trichome attachments, surrounded by radially elongate epidermal cells. Eight species of Sophora are recognized in New Zealand (Heenan et al., 2001). Based on the cuticle morphology, leaf size, and the current distribution of S. microphylla (which is widespread over the region, albeit often rare or restricted) identification of the shelter material is made with that species. However, McGlone and Wood (2019, p. 2) identified seeds from the Gibraltar Rock shelter as $S$. prostata (Buchanan, 1884), stating that they were "sufficiently distinctive that we can be confident" that the species was present. S. prostata is currently unknown in the study area, and there are no records south of the Waitaki River (i.e., within 100 $\mathrm{km}$ of the area, Heenan et al., 2018), although it is conceivable that its absence from the southern end of New Zealand might be attributed to removal by a late Holocene fire. McGlone and Wood (2019) did not expand on how seeds of $S$. prostata and $S$. microphylla could be distinguished, but the leaflets of $S$. prostata reach about $4 \mathrm{~mm}$ long (Breitweieser et al., 2010), while those of $S$. microphylla range 

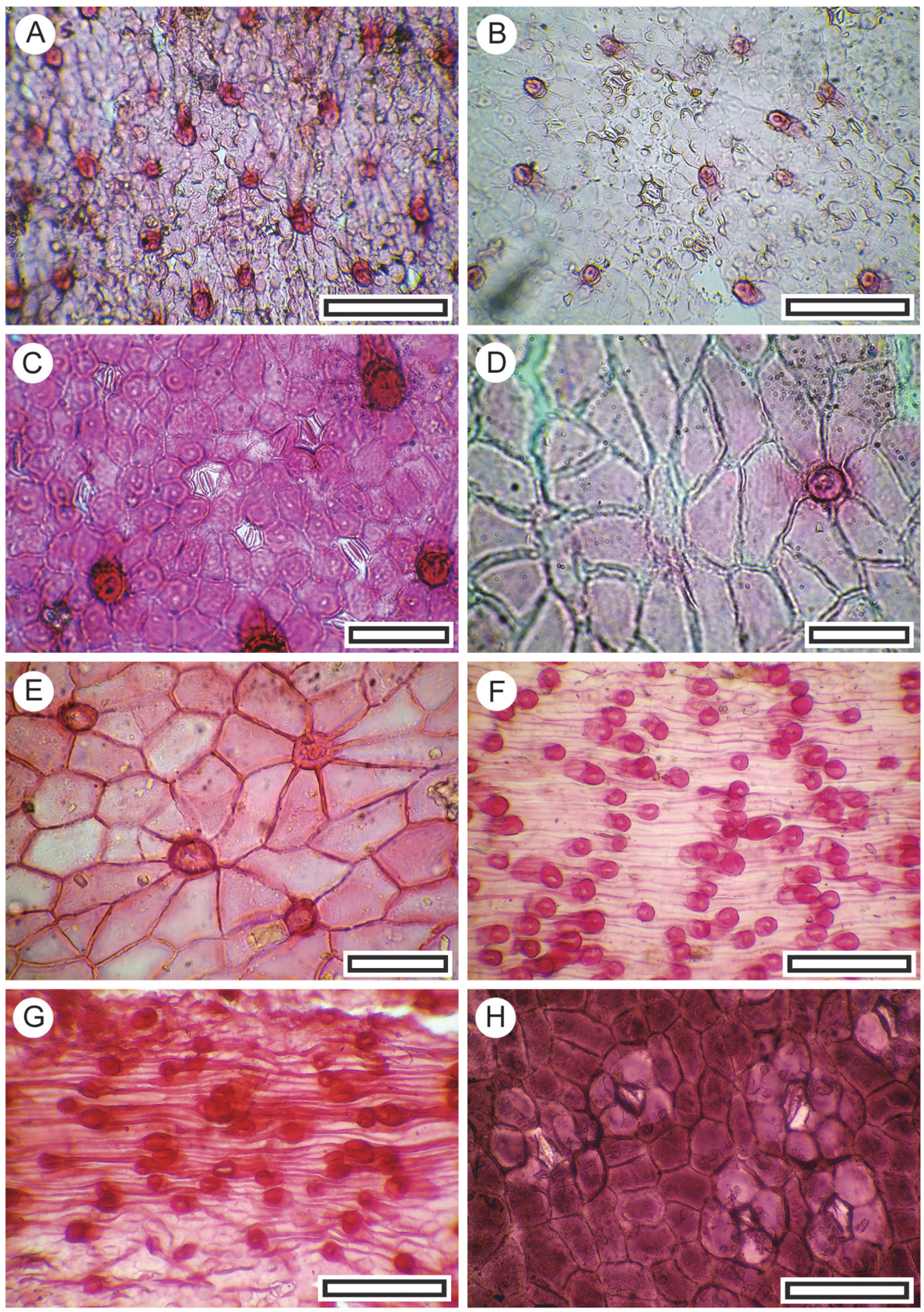

FIGURE 9. Sophora cuticle morphology (Transmitted light microscopy). A. View of S. microphylla stomatal (abaxial) surface showing deeply stained trichome bases, papillae, and stomatal complexes (LX2799, Shelter-96, scale bar equals $100 \mu \mathrm{m}$ ). B. View of S. microphylla stomatal (abaxial) surface of less-stained specimen, but still showing relatively well-stained trichome bases, papillae, and stomatal complexes (LX2590, Shelter-50, scale bar equals $100 \mu \mathrm{m}$ ). C. Detail to show stomatal complexes, partly obscured by irregular papillae (LX3052, from Coprolite-26, scale bar equals $40 \mu \mathrm{m}$ ). D. View of $S$. microphylla non-stomatal (adaxial) surface, with deeply staining trichome attachment at right (LX3052, Coprolite-26, scale bar equals $40 \mu \mathrm{m}$ ). E. View of S. microphylla non-stomatal (adaxial) surface, with four deeply staining trichome attachments. Note the characteristic radiating surrounding epidermal cells (LX3006, Shelter-76, scale bar equals $100 \mu \mathrm{m}$ ). F. View of basal portion of S. microphylla leaf mid-rib (abaxial surface), showing dense trichome attachment sites (LX3106, Shelter-39, scale bar equals $100 \mu \mathrm{m})$. G. View of another style of $S$. microphylla cuticle morphology from basal portion of the leaf mid-rib (abaxial surface), showing dense trichome attachment sites, and thinner cuticle on either side (LX3052, Coprolite-26, scale bar equals $100 \mu \mathrm{m}$ ). H. Abaxial cuticle of Sophora prostrata. Note clearly different from S. microphylla in absence of trichome attachment sites, and distinct ring of subsidiary cells around the stoma (OPH5491, scale bar equals $100 \mu \mathrm{m})$. 
from about 4.5-12.5 $\mathrm{mm}$ long. The two species are also clearly distinguishable on cuticle morphology. S. prostrata does not have the trichome bases, which are so prominent in S. microphylla, and there is a much clearer ring of subsidiary cells surrounding the stoma (pers. obs.). On both characters all the leaves found in the present study are regarded as S. microphylla, and unless otherwise indicated, further mention of 'Sophora' means S. microphylla.

Family ROSACEAE Jussieu, 1789

Genus RUBUS Linnaeus 1753

Rubus sp.

Figure 10

Material. Present in 19\% of the shelters with dry vegetation. Shelter-002, LX3338; Shelter-003: LX5421; Shelter-010: LX3185; Shelter-013: SL6704; Shelter-025: SL6680; Shelter-027: SL6462; Shelter-029: LX5808; Shelter-033: LX2988, LX2989; Shelter-042: LX2599; Shelter048: LX3324; Shelter-052: SL6532, SL6533, SL6534, SL6536; Shelter-055: LX3317; Shelter056: SL6429, SL6431, SL6433; Shelter-080: LX3016; Shelter-088: LX3288; Shelter-093: LX3303; Shelter-094: LX3005; Shelter-099: LX3025, LX3026, LX3027; Shelter-103: LX2521; Shelter-112: LX5514.

Remarks. Abaxial cuticle is easily recognized on the basis of its massive, hollow, flanged trichome attachments. The stomatal complexes are in areoles, relatively small, and with indistinct outlines and set among epidermal cells with highly sinuous outlines. Several species of Rubus occur in the region today. Distinction based on cuticle is not possible.

Family VIOLACEAE Batsch, 1802

Genus MELICYTUS Forster and Forster, 1776

Melicytus alpinus (Garnock-Jones in Connor and Edgar, 1987)

Figure 11

Material. Present in $5 \%$ of the shelters with dry vegetation. Shelter-006: LX5560; Shelter-008: SL6663; Shelter-029: LX5809; Shelter-091: LX3015; Shelter-095: LX2887, LX2888; Shelter100: LX2901.

Remarks. Stomatal complexes have prominent outer stomatal ledges and polar T-thickenings.

Family MYRTACEAE Jussieu, 1789

Genus KUNZEA Reichenbach, 1828

Kunzea ericoides (Thompson, 1983)

Figure 12

Material. Present in $2 \%$ of the shelters with dry vegetation. Shelter-062, LX3253, LX3256.
Remarks. Two leaf fragments show the typical 'lid cells' of the Myrtaceae. Based on the generally aligned stomatal complexes and the common distribution over the region today, this is regarded as Kunzea ericoides.

Family LORANTHACEAE Jussieu, 1808

Genus KORTHALSELLA Tieghem, 1896 Korthalsella sp.

Figure 13

Material. Present in $5 \%$ of the shelters with dry vegetation. Shelter-006, LX5567, Shelter-007, SL6481, Shelter-029: LX5799, LX5807, LX5803; Shelter-077, LX2552, Shelter-082, LX2450.

Remarks. Four fragments of shelter floor and two coprolite cuticles have paracytic stomata with clearly visible guard cells. The polar ends of the stomatal complexes are typically flat, while the sides curve out. The stomata are sometimes in short but distinct rows of epidermal cells, and are clearly oriented transverse to the row, while a few stomates can be perpendicular to the trend. In other areas of cuticle there are no distinct epidermal rows, and stomatal orientation is not clearly aligned. The cuticle is identified as the mistletoe Korthalsella. In reference material of extant Korthalsella, this range of stomatal distribution and orientation reflects location-near the leaf base, the stomates and intervening epidermal cells are in clear files but become less clear away from the base. No other New Zealand Loranthaceae genera have this cuticle morphology. For example, Ileostylus micranthus, a broad-leaved mistletoe found in wetter vegetation peripheral to the study area, has randomly oriented stomatal complexes. Three species of Korthalsella currently occur in the study area (Sultan, 2014), but distinguishing between them on cuticle fragments is not attempted.

\section{Family POLYGONACEAE Jussieu, 1789 \\ Genus MUEHLENBECKIA Meisner, 1841 Muehlenbeckia sp. \\ Figure 14}

Material. Present in $6 \%$ of the shelters with dry vegetation. Shelter-049: LX3333; Shelter-055: LX3313, LX3315; Shelter-062: LX3275; Shelter087: LX3307, LX3308; Shelter-095: LX2886, LX2891; Shelter-102: LX2530; Shelter-104: LX3127.

Remarks. The cuticle is recognised by the peltate trichome stalks which are bicellular, plus the ornamentation of fine ridges between the stomatal complexes.

Family MALVACEAE Jussieu, 1789

Genus PLAGIANTHUS Forster and Forster, 1776 

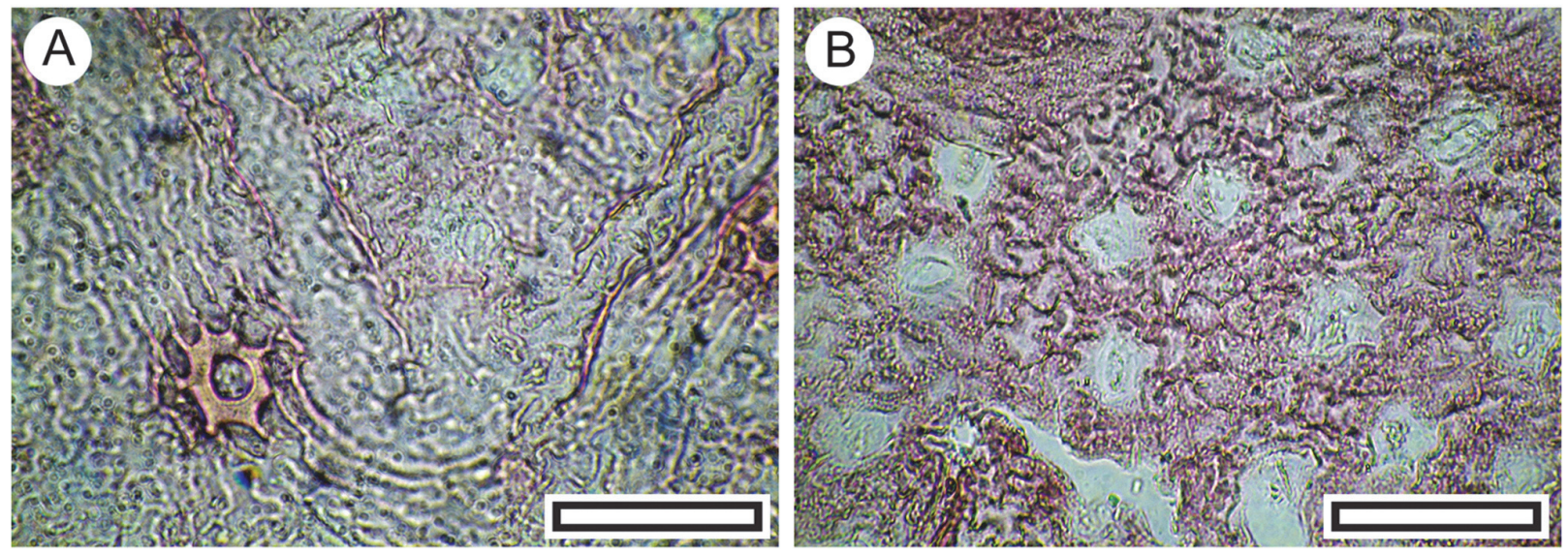

FIGURE 10. Rubus sp. cuticle morphology (Transmitted light microscopy). A. Abaxial surface, showing a typical massive, flanged and hollow trichome attachment, at left, and more poorly staining cuticle with stomatal complexes in the upper right (LX2775, Coprolite-8, scale bar equals $100 \mu \mathrm{m})$. B. A patch of stomatal complexes, showing their typically poorly defined outlines and the sinuous walls of the epidermal and subsidiary cells (LX2818, Shelter-96, scale bar equals $100 \mu \mathrm{m})$.
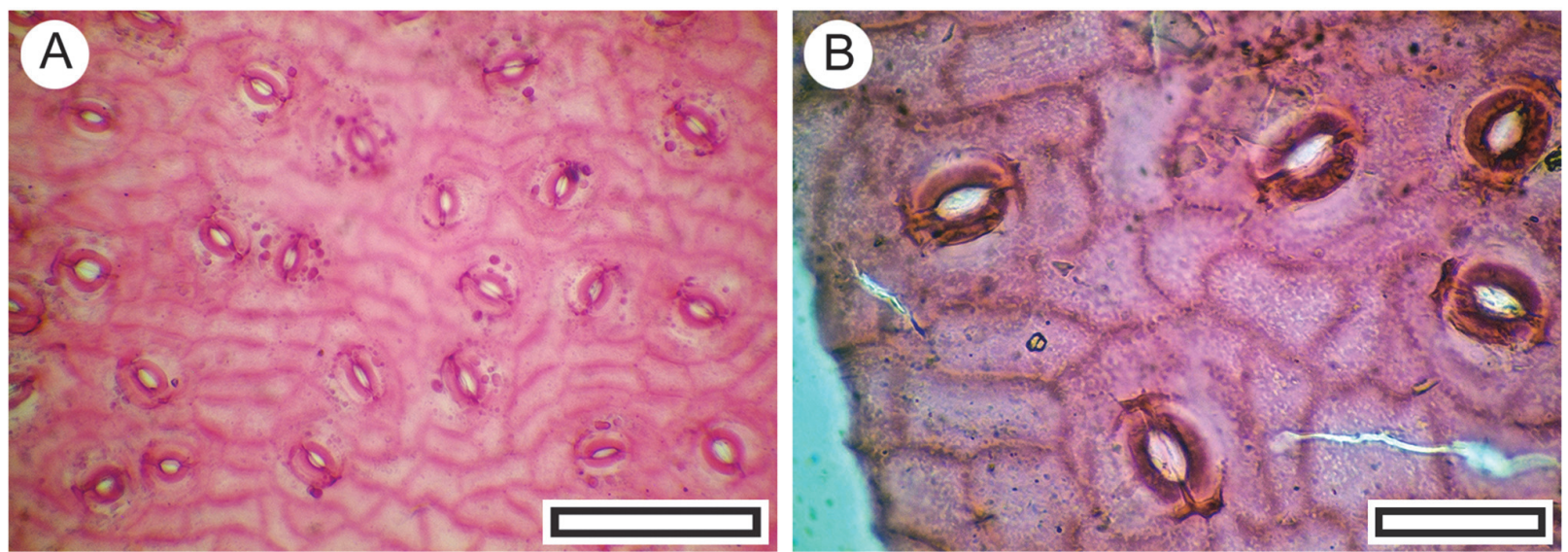

FIGURE 11. Melicytus alpinus. A. Abaxial surface, showing typical range of stomatal complexes and orientation (LX5560, Shelter-6, scale bar equals $100 \mu \mathrm{m}$ ). B. Detail of stomatal complexes showing the prominent outer stomatal ledges and thickened polar T-pieces (LX5338, Coprolite-106, scale bar equals $40 \mu \mathrm{m}$ ).
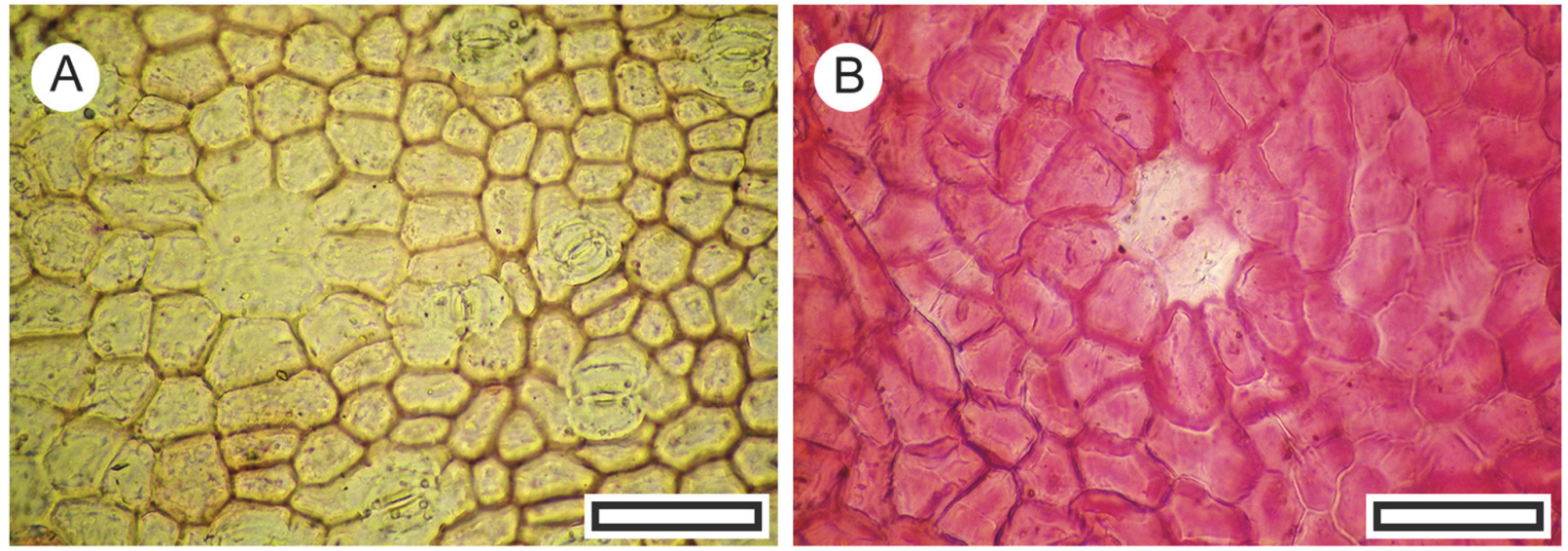

FIGURE 12. Kunzea ericoides. A. Abaxial surface, showing lid cell to left and stomatal complexes to right (LX3256, Shelter-62, scale bar equals $40 \mu \mathrm{m})$. B. Single lid cell (LX3253, Shelter-62, scale bar equals $40 \mu \mathrm{m})$. 

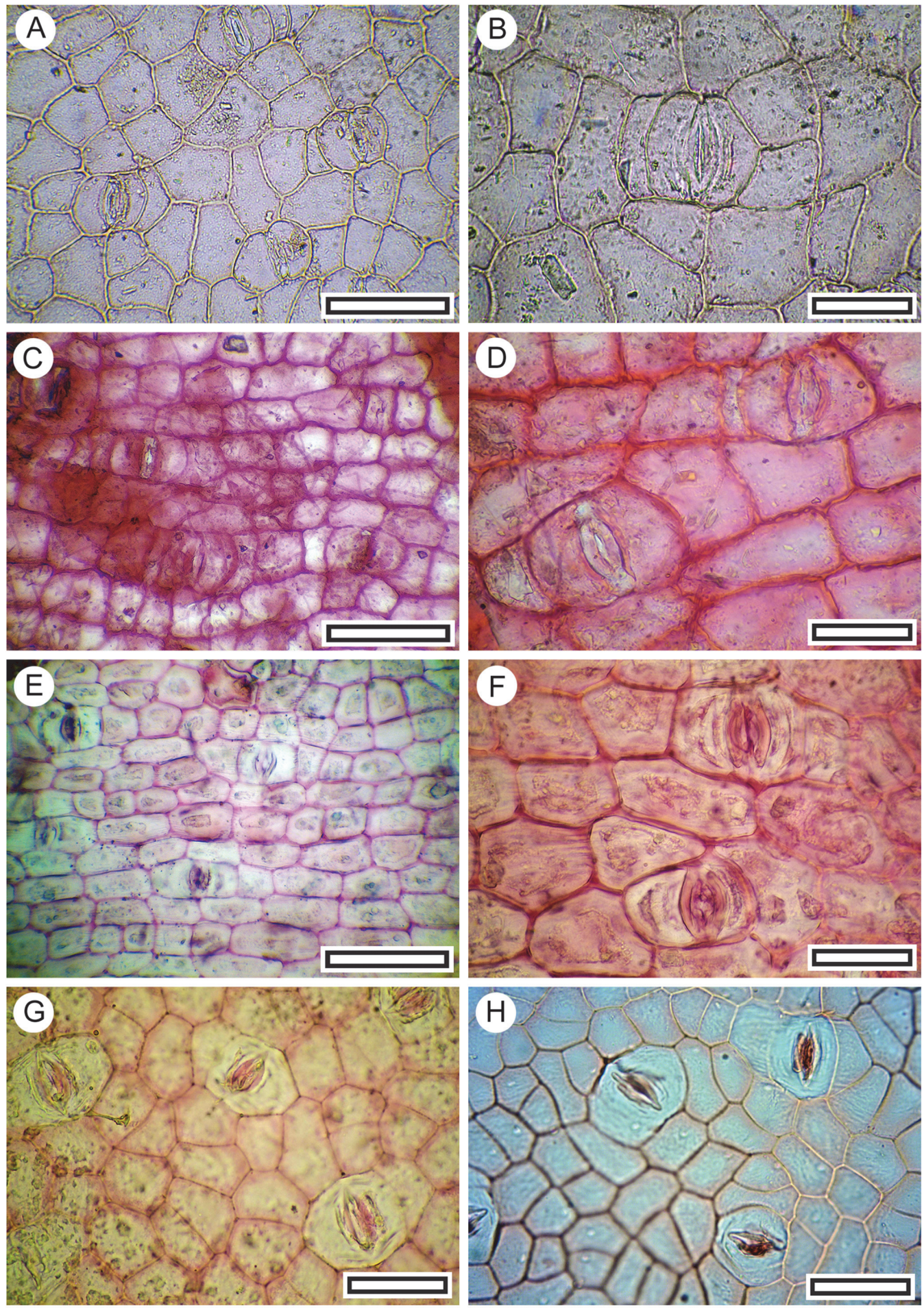

FIGURE 13. Loranthaceae (Korthalsella and Illiostylus) cuticle morphology (Transmitted light microscopy). A. Korthalsella sp., showing generally aligned stomatal complexes (LX2450, Shelter-82, scale bar equals $100 \mu \mathrm{m}$ ). B. Korthalsella sp., detail showing a single stomatal complex (LX2450, Shelter-82, scale bar equals $40 \mu \mathrm{m}$ ). C. Korthalsella sp., showing stomatal orientation perpendicular to epidermal cell rows (LX3371, Coprolite-79, scale bar equals $100 \mu \mathrm{m}$ ). D. Korthalsella sp., detail of stomatal complex (LX3371, Coprolite-79, scale bar equals $40 \mu \mathrm{m}$ ). E. Korthalsella salicornioides for comparison (Herbarium specimen, OPH9239, scale bar equals $100 \mu \mathrm{m}$ ). F. Korthalsella salicornioides for comparison (Herbarium specimen, OPH9239, scale bar equals $40 \mu \mathrm{m}$ ). G. Illiostylus micranthus for comparison (Herbarium specimen, OPH8301, scale bar equals $100 \mu \mathrm{m}$ ). H. Illiostylus micranthus for comparison (Herbarium specimen, OPH8301, scale bar equals $100 \mu \mathrm{m}$ ). 

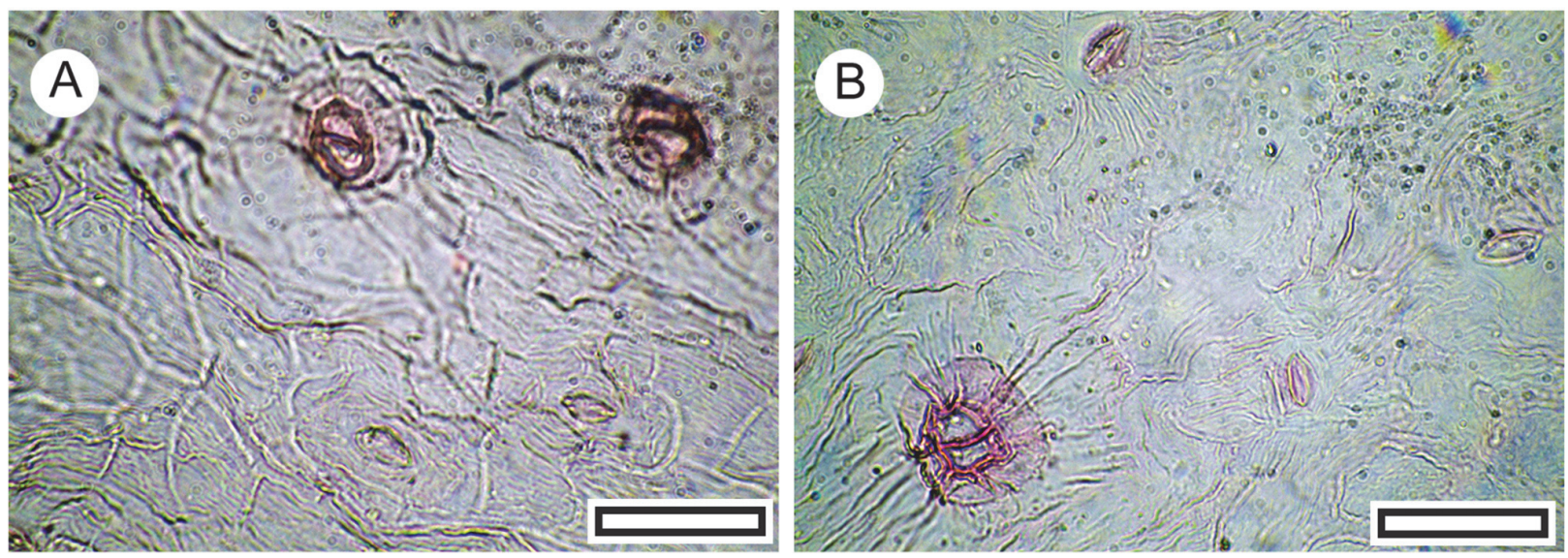

FIGURE 14. Muehlenbeckia sp. A. Abaxial surface with stomatal complexes below and peltate trichome with divided base above (LX2891, Shelter-95, scale bar equals $40 \mu \mathrm{m})$. B. Three stomatal complexes among fine surface ridging and peltate trichome with divided base at lower left (LX3100, Coprolite-36, scale bar equals $40 \mu \mathrm{m}$ ).

or HOHERIA Cunningham, 1839a

Plagianthus sp. or Hoheria sp.

Figure 15

Material. Present in 5\% of the shelters with dry vegetation. Shelter-033: LX2948, LX2950, LX2951; Shelter-040: LX3250, LX3259, LX3260; Shelter068: SL6480; Shelter-103: LX2520; Shelter-112: LX5516.

Remarks. Cuticle fragments with sessile branching (sometimes) stellate and simple glandular trichomes are Malvaceae. In the Central Otago context, based on previously described seed and bark remains (Wood and Walker, 2008; McGlone and Wood, 2019), the cuticle is most likely Plagianthus or perhaps Hoheria. However, features to distinguish between these two based on cuticles are uncertain, and further identification is not made at this stage.

\section{Family PRIMULACEAE Batsch, 1794 \\ Genus MYRSINE Linnaeus, 1753 \\ Myrsine divaricata (Cunningham, 1838b)}

Figure 16

Material. Present in $33 \%$ of the shelters with dry vegetation. Shelter-003: LX5415; LX5418, LX5395, LX5397; Shelter-005: LX5402, LX5405; Shelter006: LX5555, LX5563; Shelter-012: LX3142, LX3143, SL6718; Shelter-017: SL6604; Shelter018: LX3009; Shelter-022: SL6594; Shelter-023: SL6610; Shelter-027: SL6464, SL6465; Shelter029: LX5810; Shelter-030: LX2470, LX2472, LX2474; Shelter-032: LX2913, LX2914, LX2918, LX2919; Shelter-036: LX2974, LX2976; Shelter042: LX2600; Shelter-050: LX2557, LX2592; Shelter-056: SL6430, SL6432; Shelter-064: SL6509; Shelter-068: SL6479; Shelter-070: LX2613; Shel- ter-077: LX2553; Shelter-078: SL6474; Shelter082: LX2437; Shelter-083: LX2452; Shelter-085: LX3281; Shelter-088: LX3320; Shelter-089: LX3357, SL6447; Shelter-090: LX3268, LX3269; Shelter-092: LX2894, LX3001; Shelter-094: LX3004; Shelter-095: LX2885; Shelter-098: LX3024; Shelter-099: LX3029; Shelter-103: LX2515, LX2519, LX2522; Shelter-111: LX5504; Shelter-113: LX5517, LX5520; Shelter-114: LX5657, LX5658.

Remarks. The cuticle is easily recognized on the basis of the typically anisocytic stomatal complexes and sinuous epidermal cell walls. Most fragments will also include peltate trichomes. The nonstomatal leaf surface has a characteristic flowing ornamentation of fine flowing ridges. Intact leaves show a row of prominent glands along the apical margin. This is regarded as the divaricating dryland species M. divaricata.

Family RUBIACEAE Jussieu, 1789

Genus Coprosma Forster and Forster, 1776

Coprosma propinqua (Cunningham, 1839c)

Figure 17

Material. Present in $6 \%$ of the shelters with dry vegetation. Shelter-002: LX3338; Shelter-006: LX5573; Shelter-028: LX2941; Shelter-048: LX3325; Shelter-049: LX3334; Shelter-062: LX3254, LX3272; Shelter-097: LX2459.

Remarks. Recognised by very thin cuticle where the paracytic arrangement of subsidiary cells is reflected in the ornamentation of ridges at right angles to the stomatal axis.

Family PLANTAGINACEAE Jussieu, 1789 Genus HEBE Jussieu, 1789 

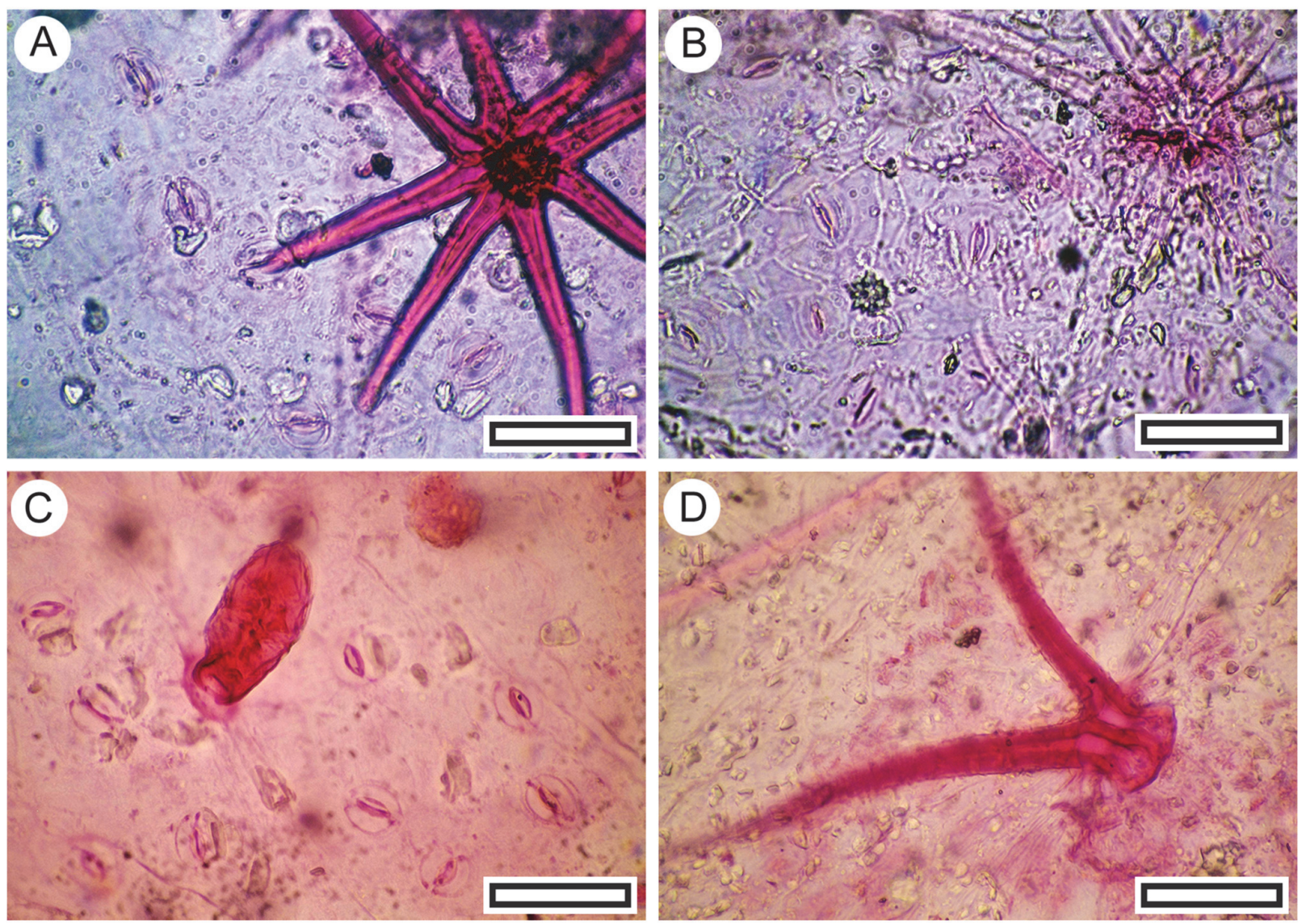

FIGURE 15. Malvaceae (Plagianthus sp. or Hoheria sp.) abaxial surface cuticle morphology (Transmitted light microscopy). A. Stellate trichome at upper right (LX2520, Shelter-103, scale bar equals $40 \mu \mathrm{m}$. B. Stellate trichome at upper right, group of stomatal complexes at lower left (LX2951, Shelter-33, scale bar equals $40 \mu \mathrm{m}$ ). C. 'balloon' trichome (LX2520, Shelter-103, scale bar equals $40 \mu \mathrm{m}$ ). D. two-armed trichome (LX2520, Shelter-103, scale bar equals 40 $\mu \mathrm{m})$.

Hebe cupressoides (Cockayne and Allan, 1927) Figure 18

Material. Present in $32 \%$ of the shelters with dry vegetation. Shelter-006: LX5551; Shelter-007: LX3345; Shelter-008: LX3344; Shelter-017: SL6617; Shelter-020: LX2946, LX2955, LX2957; Shelter-029: LX5800; Shelter-030: LX2469; Shelter-031: LX2952; Shelter-032: LX2982, LX2983; Shelter-034: LX2964; Shelter-039: LX5570; Shelter-042: LX2605; Shelter-043: LX2598; Shelter046: LX2569; Shelter-047: LX3278; Shelter-050: LX2558; Shelter-060: LX3292; Shelter-062: LX3271; Shelter-063: SL6526, SL6527, SL6528, SL6530, SL6531; Shelter-065: LX3311; Shelter066: SL6469; Shelter-070: LX2609; Shelter-074: LX2537; Shelter-075: LX2594; Shelter-077: LX2555; Shelter-078: SL6473, SL6476; Shelter079: LX5862; Shelter-083: LX2453; Shelter-088: LX3291, LX3321, LX3322; Shelter-090: LX3265, LX3267; Shelter-100: LX2902; Shelter-101:
LX2910; Shelter-110: LX3110; Shelter-111: LX5502; Shelter-114: LX5861.

Remarks. 'Whipcord' Hebe shoot fragments are frequently recovered in bulk samples exhibiting the characteristic scale-like leaves (about $2 \mathrm{~mm}$ long), arranged in opposite decussate pairs and with a 'marginal frill' of elongate cells around their apices. The cuticle has a pronounced ornamentation of dense ridges and stomata which have a general longitudinal alignment. This combination can identify smaller fragments.

Nine or 10 species of Hebe are recognized in New Zealand (Wagstaff and Wardle, 1999; Bayly and Kellow, 2006), and Hebe is placed in Veronica by some workers (Albach and Chase, 2001; Albach et al., 2004; Garnock-Jones et al., 2007). There seems to be no general agreement in New Zealand on this change, and the arguably more common usage of Hebe is followed here. Based on their small size and widely separated leaves (Wag- 

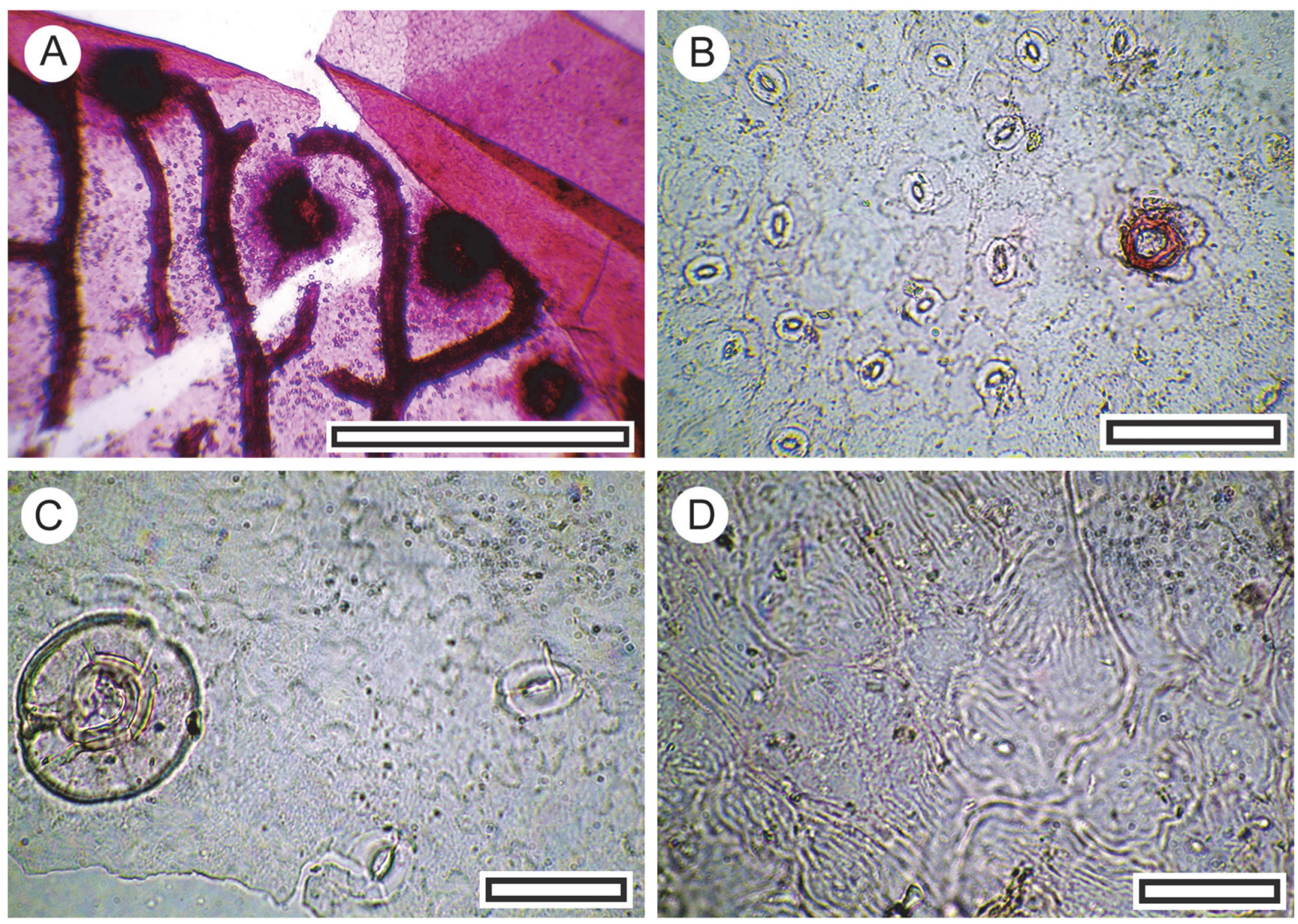

FIGURE 16. Myrsine divaricata cuticle morphology (Transmitted light microscopy). A. Margin of a leaf showing dark glandular structures, situated just inside the margin, and veins, projecting from below (LX2515, Shelter-103, scale bar equals $1 \mathrm{~mm}$ ). B. Typical abaxial surface cuticle showing scattered stomatal complexes and the stem of a peltate trichome (the cap has detached) at right (LX2557, Shelter-50, scale bar equals $100 \mu \mathrm{m})$. C. Detail showing an intact peltate trichome at left and two stomatal complexes at right. Note the highly sinuous margins of the epidermal and subsidiary cells (LX2789, Coprolite-21, scale bar equals $40 \mu \mathrm{m}$ ). D. Typical non-stomatal (adaxial) surface showing the distinctive ridged ornamentation and obscured outlines of the epidermal cells (LX2811 Shelter-96, scale bar equals $40 \mu \mathrm{m})$.
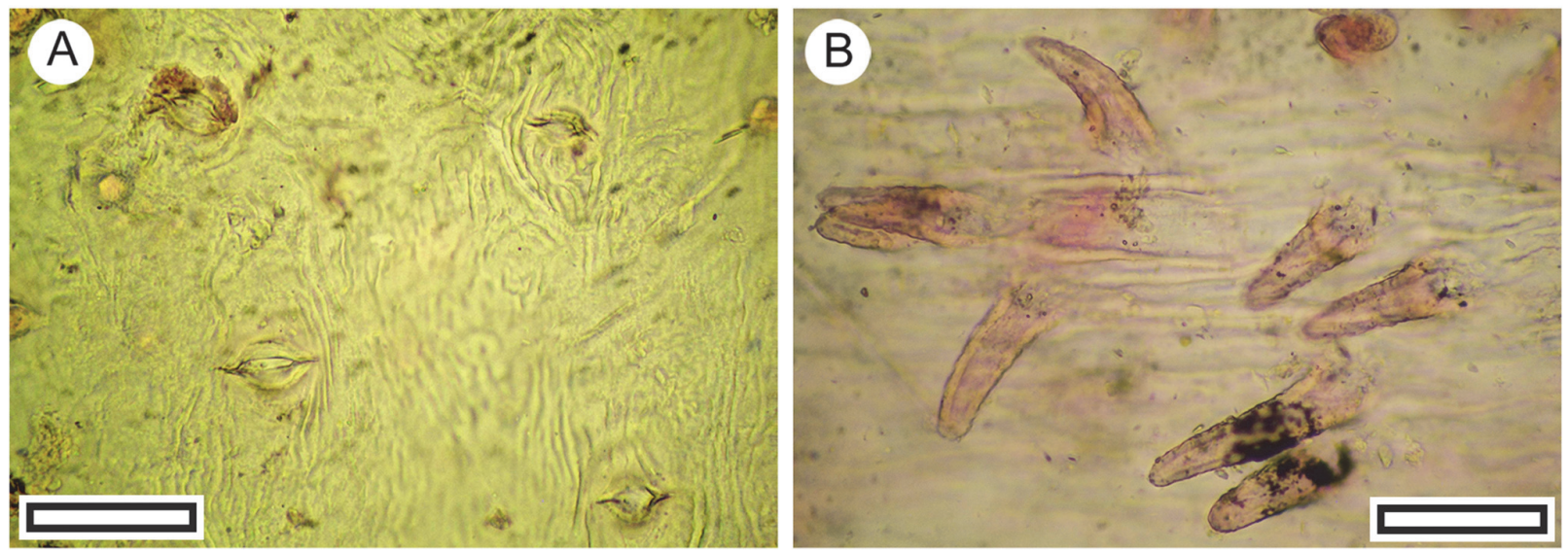

FIGURE 17. Coprosma propinqua (both LX3272, Shelter-62, scale bars equals $40 \mu \mathrm{m}$ ). A. Four stomatal complexes on abaxial surface with prominent fine ridges perpendicular to the stomatal pore. B. Zone of simple trichomes. 

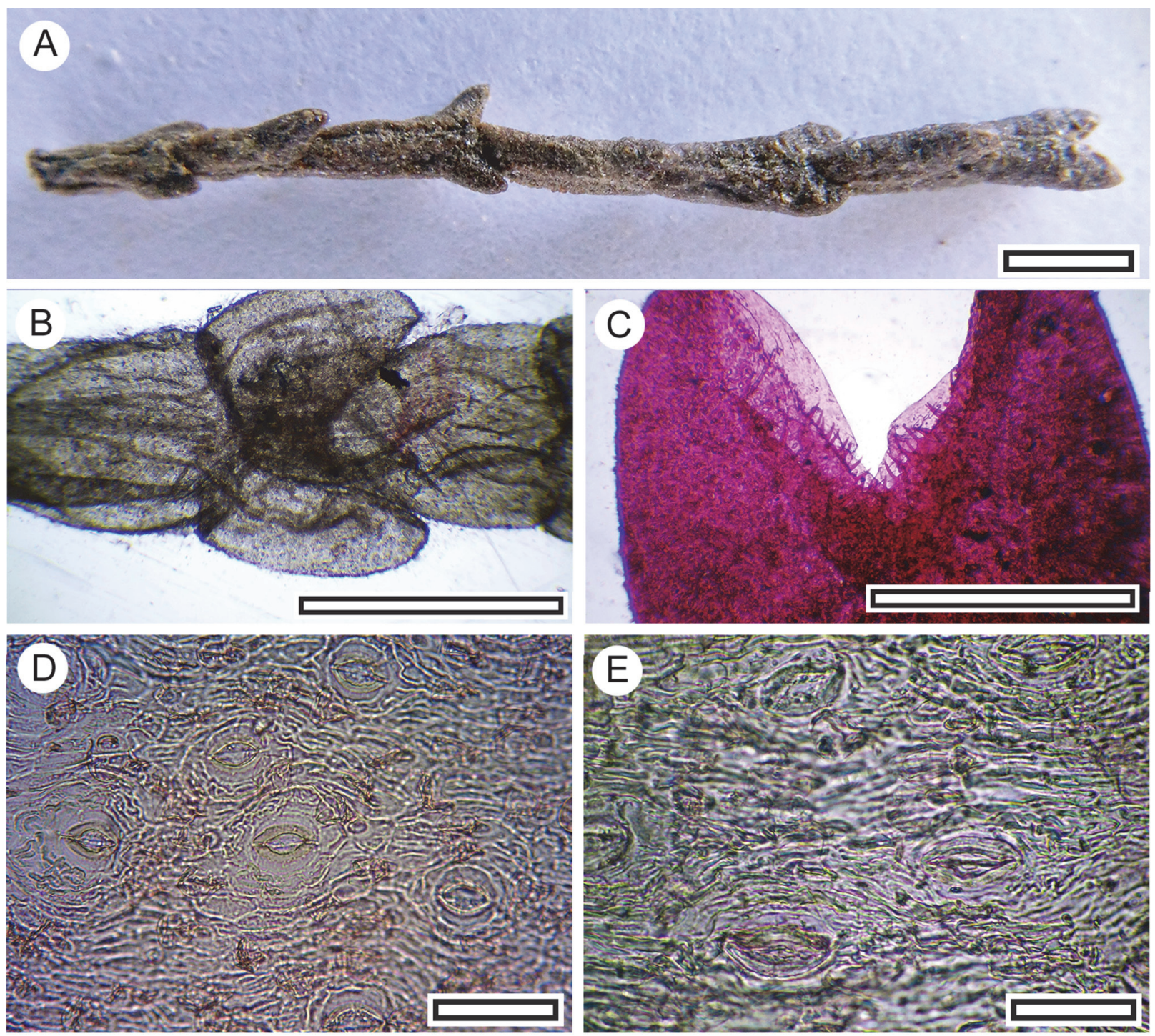

FIGURE 18. Hebe cupressoides cuticle morphology (Transmitted light microscopy). A. Section of an intact stem with paired leaves (LX5392, Shelter-7, scale bar equals $1 \mathrm{~mm})$. B. Detail of leaf pair on a stem (LX2569, Shelter-46, scale bar equals $1 \mathrm{~mm}$ ). C. Two paired leaves illustrating the 'marginal frill' at the leaf apices (LX2569, Shelter-46, scale bar equals $1 \mathrm{~mm}$ ). D. Cuticle showing generally aligned stomatal complexes on adaxial surface and an ornamentation of dense ridges (SL6473, Shelter-78, scale bar equals $100 \mu \mathrm{m}$ ). E. Detail of cuticle showing generally aligned stomatal complexes and an ornamentation of dense ridges (LX2558, Shelter-50, scale bar equals $40 \mu \mathrm{m}$ ).

staff and Wardle, 1999), and cuticle morphology, the specimens in this study are regarded as $H$. cupressoides.

Hebe pimeleoides (Cockayne and Allan, 1927) Figure 19

Material. Present in $25 \%$ of the shelters with dry vegetation. Shelter-005: LX5406; Shelter-011: LX3230, LX3231; Shelter-012: SL6716; Shelter015: SL6698; Shelter-016: SL6690, SL6692, SL6695, SL6696; Shelter-020: LX2945, LX2947, LX2960; Shelter-021: LX3149; Shelter-022: SL6593, SL6595; Shelter-025: SL6681; Shelter-
028: LX2938; Shelter-030: LX2441, LX2468, LX2967; Shelter-032: LX2985; Shelter-037: LX2995, LX2996, LX2997, LX2998; Shelter-046: LX2567, LX2577; Shelter-047: LX3276; Shelter049: LX3328; Shelter-054: LX3283; Shelter-055: LX3314; Shelter-058: SL6486; Shelter-062: LX3273; Shelter-072: LX3020; Shelter-073: SL6510; Shelter-084: LX2561, LX2895; Shelter088: LX3287, LX3290; Shelter-090: LX3270; Shelter-109: LX3237, LX3238, LX3240; Shelter-115: LX5670. 

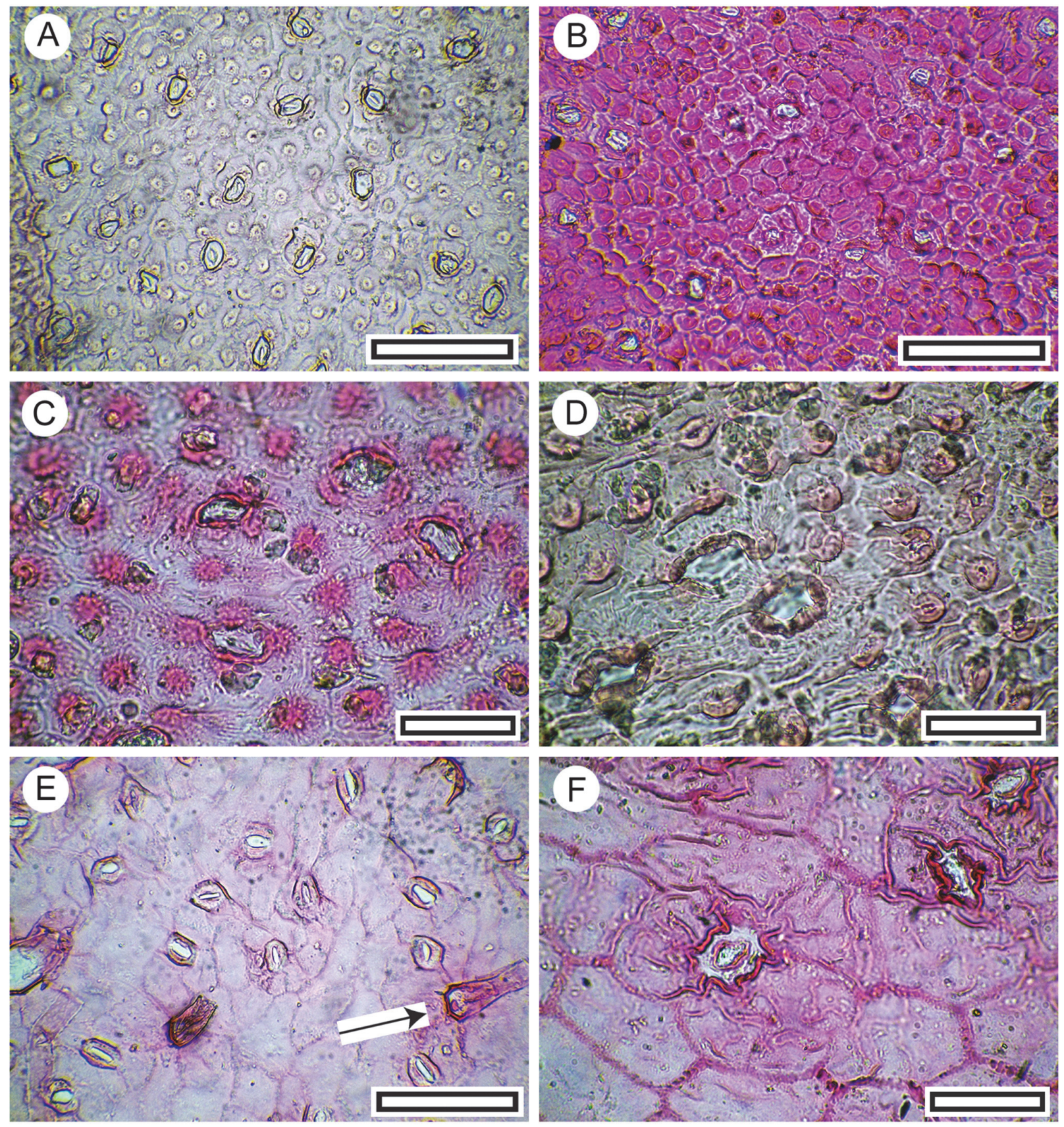

FIGURE 19. Hebe pimeleoides cuticle morphology (Transmitted light microscopy). A. Abaxial surface showing relatively small papillae and stomatal complexes (LX2468, Shelter-92, scale bar equals $100 \mu \mathrm{m}$ ). B. Abaxial surface showing relatively large papillae and stomatal complexes (LX2960, Shelter-33, scale bar equals $100 \mu \mathrm{m})$. C. Abaxial surface detail showing slightly flanged papillae and stomatal complexes (LX2938, Shelter-39, scale bar equals 40 $\mu \mathrm{m})$. D. Abaxial surface detail showing slightly smoother papillae and stomatal complexes (LX2947, Shelter-33, scale bar equals $40 \mu \mathrm{m}$ ). E. Adaxial surface showing lack of papillae and trichome bases (one is arrowed, LX2959, Shelter33, scale bar equals $100 \mu \mathrm{m}$ ). F. Abaxial surface detail showing two stomatal complexes (LX2997, Shelter-51, scale bar equals $40 \mu \mathrm{m})$. 

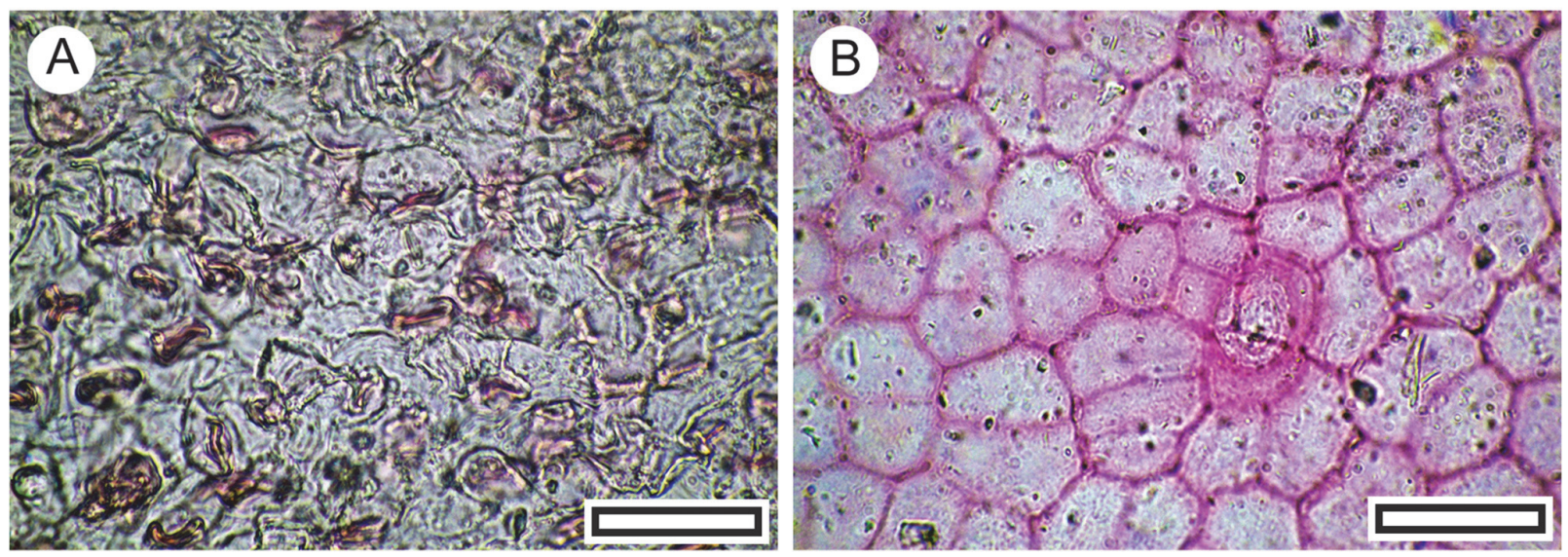

FIGURE 20. Olearia sp. cuticle morphology (Transmitted light microscopy). A. Abaxial surface showing a dense mass of trichome bases obscuring most stomatal complexes (LX2495, Coprolite-13, scale bar equals $40 \mu \mathrm{m}$ ). B. Non-stomatal (adaxial) surface showing a trichome attachment scar extending over several epidermal cells (LX3147, Shelter12 , scale bar equals $40 \mu \mathrm{m})$.

Remarks. This Hebe species has small $(7-10 \mathrm{~mm}$ long) leaves (i.e., it is not a 'whip cord'). Fragments can be recognised by cuticle, which is unequally amphistomatic, with stomatal apertures surrounded by a sharply defined and irregularly shaped rim (often a narrow ellipse). On one leaf surface the area in between the stomata is relatively smooth and in the other, the normal epidermal cells each have a central papilla.

\section{Family ASTERACEAE Berchtold and Presl, 1820 Genus OLEARIA Moench, 1802 Olearia sp. \\ Figure 20}

Material. Present in $10 \%$ of the shelters with dry vegetation. Shelter-003: LX5419; Shelter-005: LX5404, LX5409; Shelter-006: LX5556; Shelter012: LX3146, LX3147; Shelter-025: LX3177; Shelter-029: LX5806; Shelter-030: LX2440; Shelter043: LX2596; Shelter-095: LX2890; Shelter-097: LX2458, LX2460, LX2462; Shelter-098: LX3023.

Remarks. Abaxial cuticle with dense, squat trichome bases and stomatal complexes which have an indistinct outline, but an ornamentation of fine ridges, and adaxial cuticle with clearly defined, relatively large, isodiametric epidermal cells, and mostly no trichome bases is regarded as Olearia. There are also fragments of adaxial cuticle with multi-cellular trichome attachment scars, also regarded here as Olearia. However, Olearia is a diverse genus, and while some fragments are consistent with locally occurring species such as $O$. lineata (Cockayne, 1910), like the Poaceae, a much larger reference collection is needed to clarify identification at the species level.
Family PITTOSPORACEAE Brown, 1814 Genus PITTOSPORUM Banks and Solander, 1788 Pittosporum tenuifolium (Banks and Solander, 1788)

Figure 21

Material. Present in $27 \%$ of the shelters with dry vegetation. Shelter-001: LX2715, LX2717; Shelter007: SL6600, SL6601; Shelter-008: SL6666; Shelter-010: LX3183, LX3323, SL6706; Shelter-017: LX3171, LX3172, LX3174, LX3175, SL6616, SL6618, SL6626; Shelter-020: LX2956, LX2958, LX2961; Shelter-029: LX5801; Shelter-030: LX2443, LX2471, LX2475; Shelter-032: LX2984; Shelter-036: LX2975; Shelter-037: LX2943, LX2944; Shelter-039: LX5572; Shelter-046: LX2565, LX2572, LX2574, LX2576; Shelter-047: LX3280; Shelter-050: LX2587, LX2589, LX2593; Shelter-056: SL6434; Shelter-058: SL6485; Shelter-064: LX3450, SL6460, SL6505, SL6507, SL6508; Shelter-071: SL6435; Shelter-073: SL6513; Shelter-077: LX2556; Shelter-078: SL6471, SL6472; Shelter-083: LX2454, LX2455, LX2457, SL6539; Shelter-090: LX3264; Shelter100: LX2898, LX2899; Shelter-101: LX2905; Shelter-112: LX5510, LX5511, LX5512, LX5513; Shelter-113: LX5518, LX5519.

Remarks. $P$. tenuifolium leaves and fruits have already been recorded from Central Otago shelters (Wood and Walker, 2008). Fragments of leaf cuticle are readily recognized on the basis of paracytic stomatal complexes, broad, smooth ridges marking the anticlinal epidermal cell walls, distinctive deeply staining trichome attachment sites, which usually have irregular and diffuse edges (sometimes with 

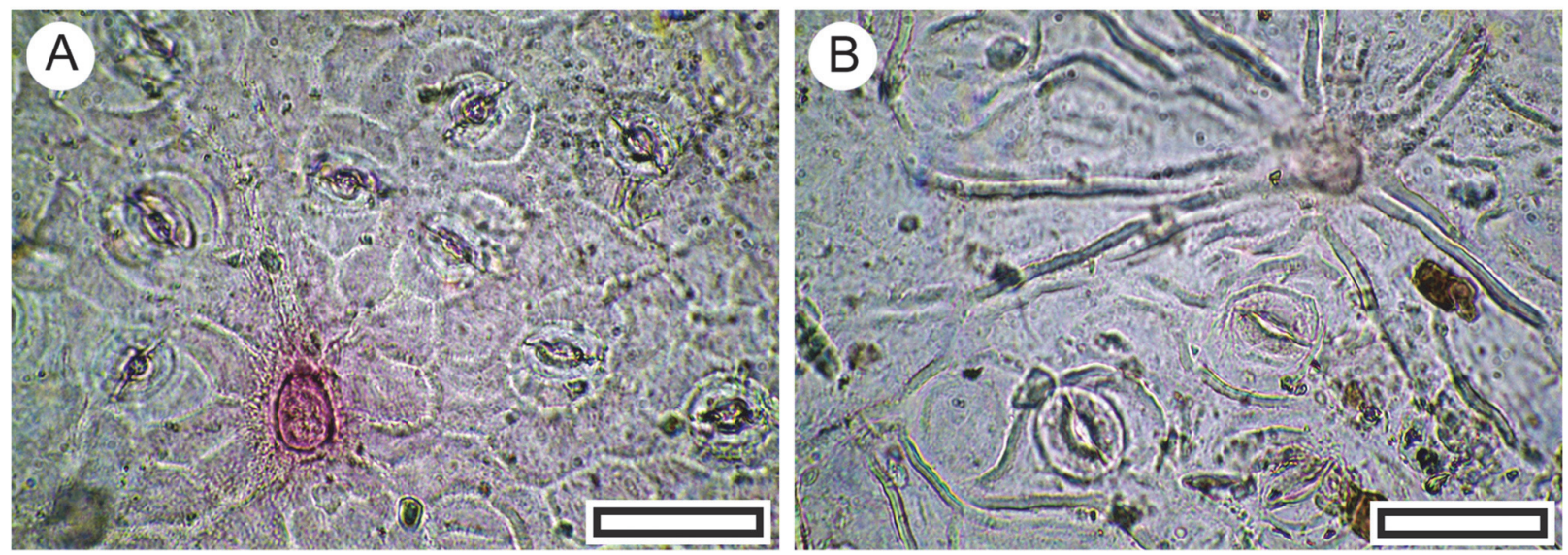

FIGURE 21. Pittosporum tenuifolium cuticle morphology (Transmitted light microscopy). A. Paracytic stomatal complexes on adaxial surface with a relatively sharply bounded trichome base at lower left (LX2576, Shelter-63, scale bar equals $40 \mu \mathrm{m})$. B. Paracytic stomatal complexes on abaxial surface with a more typical indistinctly bounded trichome base at upper right (LX2455, Shelter-111, scale bar equals $40 \mu \mathrm{m})$.

the persistent bases of trichomes), and occasional larger stomatal complexes. The trichome attachment sites and larger stomatal complexes are surrounded by radiating fine ridges.

$$
\begin{gathered}
\text { Family ARALIACEAE Jussieu, } 1789 \\
\text { Genus PSEUDOPANAX Koch, } 1859 \\
\text { Pseudopanax ferox (Kirk, 1889) }
\end{gathered}
$$

Figure 22

Material. Present in $4 \%$ of the shelters with dry vegetation. Shelter-001: LX2711, LX2712; Shelter037: LX3111; Shelter-066: SL6467; Shelter-094: LX2884.

Remarks. An intact Pseudopanax ferox leaf was found at Gibraltar Rock and Sbag 0870 (LX3111, ConcJar 2204). This, and cuticle fragments from other shelters, show the ring of subsidiary cells, and prominent outer stomatal ledges which are surrounded by a ring of thin, finely ridged cuticle, which is typical of Pseudopanax. This specimen also shows the normal epidermal cells which are much smaller than the stomatal complexes, and tangentially oriented subsidiary cells, which distinguish $P$. ferox from Pseudopanax crassifolious Koch (1859). The later has much larger normal epidermal cells, and larger, more irregularly shaped subsidiary cells. $P$. ferox is considered to have existed in mid-late Holocene Central Otago (Walker et al., 2004b; Rogers et al., 2005), but to date, not $P$. crassifolious. However, a single relict specimen of $P$. crassifolious is living in the Waikerikeri Valley (pers. obs.), indicating both species were likely in the region, and recognising the difference is important.

\section{Coprolites}

\section{Moa Coprolites \\ Figure 23}

Coprolites were found in 20 shelters. Thirtyeight coprolites were examined for their leaf cuticle content (Appendix 3, with approximate dimensions), and a selection of the larger ones are illustrated in Figure 23. When coprolite size is plotted on Wood and Wilmshurst (2014, fig. 3), one group, Coprolites-8, 13, 21, 30, 34, 37, 83, 94, 96, fall within the range of genetically determined moa, but might conceivably be kakapo (Figure 24). However, a second group, Coprolites-11, 14, 15, 16, 25, $26,27,29,60,62,111$, are well outside the range of kakapo, and their identity as moa is virtually certain. In addition, nothing is known about coprolites of the extinct 'South Island Goose' (Cnemiornis calcitrans) another potential source of confusion. A coprolite was figured by Wood and Wilmshurst (2014, fig. 4B) as "cf. Moa or South Island Goose", but like the kakapo, its size is below the upper size range regarded here as moa. Recognizable leaf fragments across the range of coprolites included Carmichaelia. sp. (one coprolite), Coprosma sp. (one coprolite), Hebe lycopodioides (one coprolite), Korthalsella sp. (two coprolites), Muehlenbeckia sp., Myrsine divaricata (seven coprolites), Olearia sp. (two coprolites), Pittosporum tennuifoilum (six coprolites), Poaceae (five coprolites), Pseudopanax ferox (one coprolite), Rubus sp. (four coprolites), and Sophora microphylla (19 coprolites). In total, the moa coprolites contain nearly the full range of plant taxa found in the shelters. Of 16 coprolites of moa size, nine contained Sophora, and 

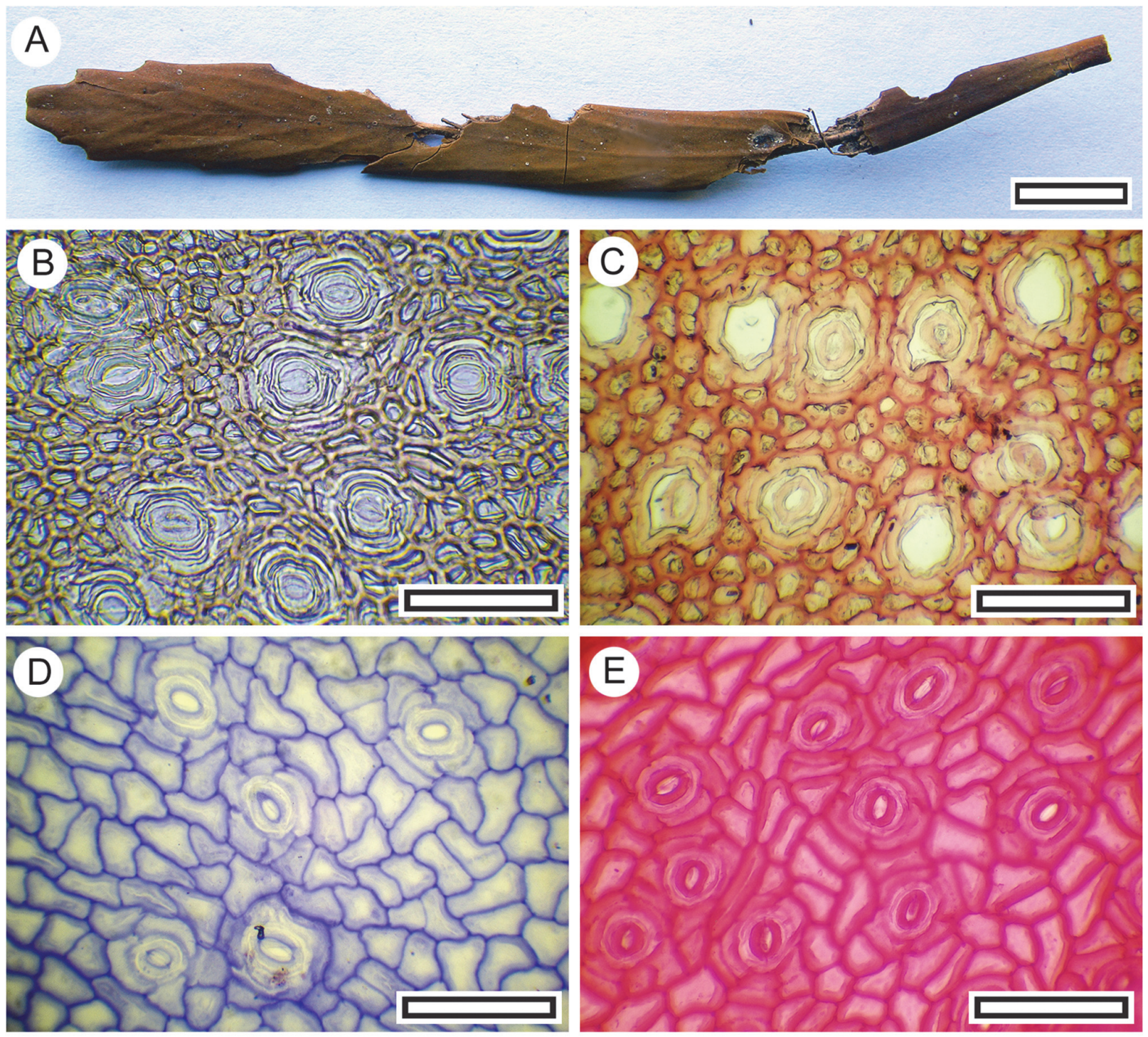

FIGURE 22. Pseudopanax leaf (reflected light) and cuticle morphology (transmitted light microscopy). A. Intact Pseudopanax ferox leaf (LX3111, Shelter-37, scale bar equals $10 \mathrm{~mm}$ ). B. Pseudopanax ferox stomatal complexes on abaxial surface (LX2711, Shelter-1, scale bar equals $100 \mu \mathrm{m})$. C. Pseudopanax ferox (LX5490, Coprolite-15, scale bar equals $100 \mu \mathrm{m})$. D. Pseudopanax crassifolious, abaxial surface showing much larger and more irregular epidermal cells (modern reference material, OPH5338, scale bar equals $100 \mu \mathrm{m}$ ). E. Pseudopanax crassifolious, abaxial surface also showing much larger and more irregular epidermal cells (modern reference material, OPH9835, scale bar equals $100 \mu \mathrm{m})$.

seven did not. Coprolite-15 (from the same Kawarau Gorge shelter that Wood et al. (2013) determined the moa that produced it to have been "predominantly a herbfield grazer") contained six species, including the trees Pittosporum tennuifolium, Pseudopanax ferox, and Sophora microphylla.

\section{DISCUSSION}

\section{A New View of the mid-late Holocene Regional Vegetation}

Holdaway (1989) proposed that Sophora was likely much more common than at present over the dry parts of Otago and Canterbury in pre-human times. He cited a patch on the Rakaia River (reported by Molloy, 1971) as a relict of the vegetation type. Later modelling work (Walker et al., 2003), placed the Kawarau and Cromwell Gorge 

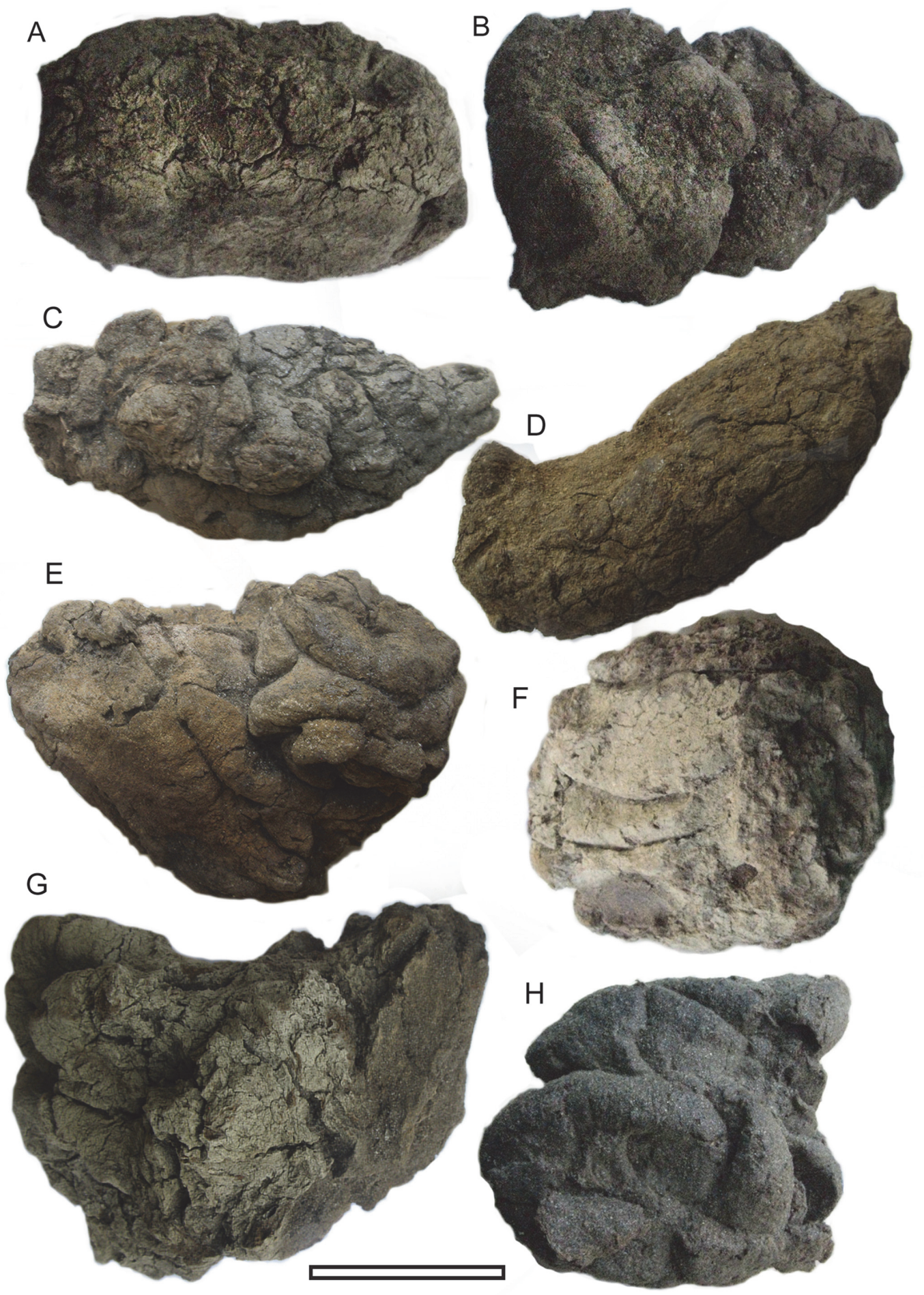

FIGURE 23. Coprolites regarded here as moa, based on their size (scale bar equals $30 \mathrm{~mm}$ ). A. Coprolite-25, containing Poaceae (Shelter-32). B. Coprolite-26, containing Pseudopanax ferox, Pittosporum tennuifolium, Sophora microphylla (Shelter-32). C. Coprolite-15, containing Coprosma sp., Olearia sp, Pittosporum tennuifolium, Pseudopanax ferox, Rubus sp., Sophora microphylla (Shelter-102). D. Coprolite-111, containing Sophora microphylla, Pittosporum tennuifolium, Rubus sp., ?Hebe (Shelter-50). E. Coprolite-16, containing Sophora microphylla, Hebe ?cupressoides (Shelter-102). F. Coprolite-62, containing Sophora microphylla (Shelter-70). G. Coprolite-14, containing Hebe cupressoides, Sophora microphylla, Rubus sp., Pittosporum tennuifolium (Shi.e. elter-102). H. Coprolite-60, containing Sophora microphylla (Shelter-103). 


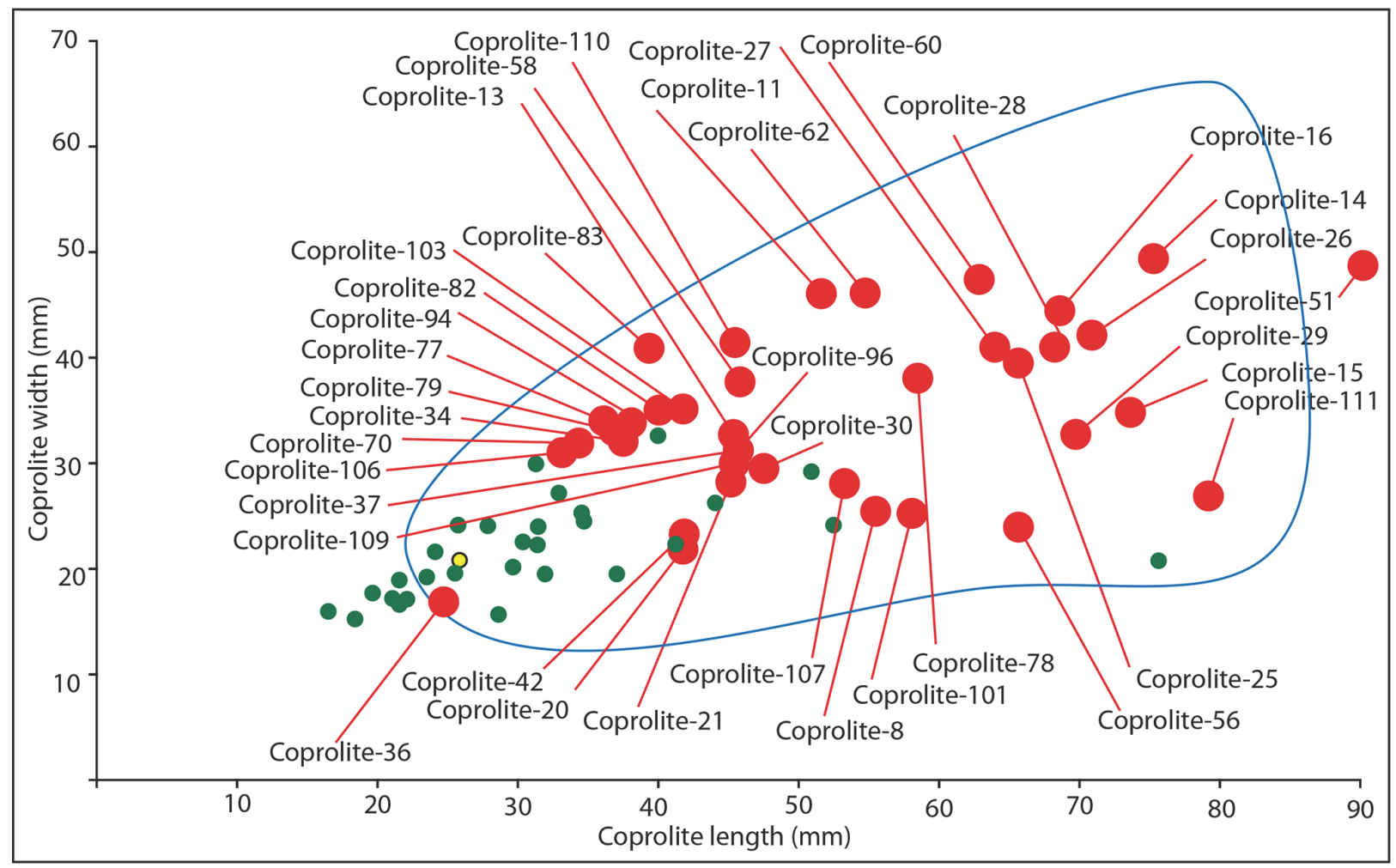

FIGURE 24. Length and width dimensions for coprolites investigated for cuticle in this work (red dots), overlain on a summary of Wood and Wilmshurst $(2014$, fig. 3). The blue curve contains the range of genetically confirmed moa coprolites in their study, and the small yellow dot indicates the size of their one genetically determined kakapo coprolite, and the green are those of their 'putative' kakapo coprolites. There is a clear group of coprolites in the present study which are well beyond the range of even 'putative' kakapo, and are regarded as moa (Coprolites-11, 14, 15, 16, $25,26,27,28,29,51,58,60,62,78,110,111)$.

localities of this study into a 'Kanuka-kowhai woodland' zone (i.e., Kunzea-Sophora), and later as 'biogeographic Zone l' (Walker et al., 2004b). This is the driest zone of the dry core of New Zealand. The samples from the upper Roxburgh Gorge in the present study fall into the slightly moister 'Kowhai-kanuka woodland' and 'Kowhai woodland' of Walker et al. (2003), which became biogeographic zones II and III in Walker et al. (2004b). On the basis of current plant distributions, Walker et al. (2004b) predicted all three zones would naturally be dominated by Sophora microphylla, Kunzea ericoides, and Leptospermum scoparium.

Rogers et al. (2005) reproduced a map of potential dryland vegetation by Leathwick et al. (2004, published as a poster) which, in contrast to the trees emphasised by Walker et al. (2003, 2004b), predicted only 'Scrub, shrubland and tussock-grassland below treeline' for the core of Central Otago (including the Roxburgh Gorge and lower altitude Cromwell Gorge) and at altitude some 'Hall's totara/broadleaf forest'. Drawing on the previous studies, Rogers et al. (2005) proposed their own "seven broad vegetation types for pre-settlement dryland South Island". These weren't mapped, but of relevance here are 'Dry angiosperm shrubland -low forest' on the "coldest and driest basins and valleys", with "rich array of shrubs and low trees" including Olearia, Sophora prostrata, and Hebe cupressoides", 'Dry conifer shrubland-low forest' on "low fertility, glacio-fluvial outwash terraces", where Phyllocladus and Halocarpus dominated, and 'Dry hardwood forest' found in "dryland hill-country", which included a wide range of angiosperms, including "kowhai" (Sophora), Pittosporum tenuifolium, Pseudopanax, and Olearia, while Podocarpus was the main conifer. The Leathwick et al. (2004) map has since been made available online (Leathwick et al., 2012).

In contrast to this, a New Zealand-wide ecosystem process model (Hall and McGlone, 2006) predicted that a 'cool dry podocarp' forest biome dominated by Prumnopitys taxifolia and Podocar- 
pus laetus "in the driest, frostiest basins of the south-eastern South Island", Podocarpus laetusdominant forest "on the surrounding lower slopes", and mixed Nothofagus-Podocarpus forests that "blended into pure [Nothofagus] forest with elevation". Their figure 1 confirms that the podocarpdominant forest was predicted for the lower gorges in the present study region. However, they noted that their "model's prediction for these now deforested inland areas was at variance with fossil evidence, which suggested a small-leaved angiosperm shrubland and grassland on the basin floors (McGlone, 2001)." They also noted that Walker et al.'s. (2004b) model "also reconstructed low forest and shrubland with little conifer presence ... as may be expected from a model based on a pattern of severely fire-censored modern vegetation". They speculated that the "basin floor discrepancy" may have been the result of "infrequent fire or climatic disturbances, such as ... exceptional frosts" which "prevented succession by the taller long-lived podocarp tree species".

But using plant macrofossils, Wood and Walker (2008, p. 250) reached a different conclusion to both Hall and McGlone's (2006) model (conifer forest), and the Walker et al. (2004) model (other than Kunzea and Leptospermum - ubiquitous Sophora). They concluded that vegetation in the gorges was a "Coprosma-Olearia-Corokia shrubland with interspersed taller broadleaf-podocarp forest". This was reiterated by Wood et al. (2008) who wrote of the "shrubland with herb-rich understories that existed throughout the Central Otago river gorges" and Wood et al.'s (2013) summary of moa coprolite content from a Kawarau Gorge and a Roxburgh Gorge shelter as indicating that the moa species (Pachyornis elephantopus) was "predominantly a herbfield grazer".

Most recently, McGlone et al. (2017, p. 15), concluded that "the driest regions of the central southeastern South Island, and intermontane valley bottoms of the eastern central Southern Alps had Phyllocladus alpinus and Halocarpus bidwillii low forest to scrub cover," and that these dryland forests "would have been heavily stocked with conifers over a low and subordinate canopy of small angiosperm trees".

In the context of these remarkably different views as to what grew in the pre-human Holocene of the driest part of Otago, the macrofossil evidence presented here prompts a new consideration of mid-late Holocene vegetation in Central Otago. The primary assumption in reconstructing the regional vegetation is that the bulk shelter material is somehow representative of that vegetation, despite passing through the taphonomic filter of the agency that brought it there - presumably birds - as roost or nesting material, (e.g., Wood, 2008; Wood and Walker, 2008) or perhaps in some cases, as degraded coprolites (Wood et al., 2008). The wide range of plant material that the birds were bringing to the shelters is instructive - from the tough, fibrous stems of Carmichaelia, to delicate Sophora, thorny Rubus, and from narrow grass to broad-leaved Pittosporum. While these birds surely had some preferences, it's a reasonable assumption that they were simply bringing in what was common.

In the present study, quantification is at the level of the shelters - their deposits are seen as time-averaged samples of the surrounding vegetation. It is proposed that in the broadest sense, the proportion of shelters containing a taxon will reflect its presence (most likely biomass) in the surrounding vegetation. The striking result of the present study is the overwhelming presence of Sophora microphylla. Its leaves are present in $75 \%$ of the 109 shelters that had dried vegetation, and in 95\% of shelters from which four or more taxa were recorded. It also tended to be the most abundant taxon in the samples where it was present. This contrasts with the present situation where it is distributed over a wide area, but uncommon and relictual. It is not regarded as an important plant in the study region now (Hubbard and Wilson, 1988). Sophora microphylla would have been the largest tree in the lower Cromwell Gorge area during the gold-rush (c. 1861-1862) and must have come under intense pressure for fuel. In this context it is surprising that some large trees, likely pre-dating European arrival, still remain. The name 'Firewood Creek', near Cromwell, may refer to the grove of Sophora which still exists there, near the road, or less likely to the Podocarpus that grow much higher in the catchment. Walker et al. (2009) regard it as now "more common than formerly", but there are no cases where Sophora could directly provide litter to a shelter. Typically, there are no Sophora growing within several tens of meters, or even kilometres of the shelters. The nearest Sophora are typically a few solitary mature individuals widely separated from others.

Wood and Walker (2008) found Sophora sp. leaves in just one of their rock shelters and in Earnscleugh Cave but found seeds of Sophora sp. in five out of 11 shelters. The significantly higher Sophora leaf presence found in the present report likely reflects the method of using cleared and 
stained cuticle. In Central Otago Holocene palynological studies, Sophora pollen presence ranges from absent to low. Sophora pollen was not mentioned at all by McGlone et al. (1995) in any of the three upland sites they investigated, or by McGlone and Moar (1998) in five, mostly lower and drier sites. However, in the mid-slope Earnscleugh Cave, Sophora pollen was absent before 1552 years BP, but later reached a maximum of $<5 \%$ before vanishing again (Clark et al., 1996). As this peak was stratigraphically about halfway between the 1552 BP date and the present, the peak might coincide with the onset of anthropogenic burning. However, Sophora pollen formed $8.7 \%$ in the Gibraltar Rock shelter (McGlone and Wood, 2019), and its seeds were also prominent (see also M.S. McGlone, pers. comm. in Wardle, 2001a, p. 540). The discrepancy between the abundance of Sophora macrofossils found here and the rare or absent pollen in other work is likely to be a consequence of its insect-pollination and low pollen production (points made by Holdaway, 1989 and Walker et al., 2004). However, in a personal communication with Holdaway (1989), M.S. McGlone countered this explanation by noting that there is apparently little Sophora charcoal known. But very little Holocene charcoal is known from the driest parts of Otago and anyway. Wardle's (2001a) study on Holocene charcoal in the Upper Clutha is from a wetter area, and it is not surprising that the charcoals there were largely from conifers and Nothofagus. Cox and Mead's (1963) results from central Canterbury, a relatively dry region, are more relevant. They found that Sophora, along with Prumnopitys taxifolia (matai), were the two most common charcoal types.

Today, the isolated trees or small clusters of S. microphylla are the tall exceptions in a vegetation that is shrubland, grassland, and a good deal of bare rock. Their occurrences are almost entirely restricted to very rocky and therefore fire-sheltered spots. The widespread occurrence of $S$. microphylla amongst the dried plant remains in the rock shelters suggests their far higher presence in prehuman times. To put this into some perspective, the number of shelters from which Sophora remains have been found, is probably more than the number of relict trees in the area where the shelters occur. A straight-forward interpretation, combining the virtually ubiquitous and common presence of Sophora microphylla remains in the shelters, plus the highly restricted distribution of relictual, tree-sized individuals today, is that prehuman vegetation in the lower parts of the gorges was dominated by S. microphylla, both in numbers and biomass. This is in agreement with Walker et al., (2004), but not with Wood and Walker (2008). Furthermore, some of the relict Sophora microphylla trees have a girth of over $2 \mathrm{~m}$ and a height of several meters (one listed 'champion tree' near Clyde has an estimated height of $14 \mathrm{~m}$, and a girth of over $3 \mathrm{~m}$ : register.notabletrees.org.nz). The situations that these specimens survive in are probably a trade-off between fire-protection and good soil. In good conditions, they may have grown larger. In the absence of fire, there is little reason why Sophora trees would not have grown densely, and as such, would have formed the continuous canopy of a 'forest'. This might have been the discontinuous canopy covered by terms such as 'open forest', perhaps 'woodland' (Specht, 1972), or 'treeland' (Atkinson, 1985), or even 'shrublandlow forest' (Rogers et al., 2005), but it was certainly something taller and more closed than 'shrubland'. In this respect, Webb (1993) noted that Sophora is surprisingly shade-tolerant and considered that it was once a forest tree (noting that it can still be seen in forest on Banks Peninsula). The results of this study are entirely consistent with what is the only large tree in the region now, Sophora, being the dominant element in the absence of fire and other human influence. They suggest Sophora was abundant through the lower gorges, and formed a low, Sophora microphylla-dominated forest.

Prior to the present study, Pittosporum charcoal was noted from the 'Rockfall l' archaeological site in the Cromwell Gorge by Ritchie (1982), and seeds, capsules, and leaves were documented from shelters by Wood and Walker (2008). Pseudopanax seeds recorded from Gibraltar Rock and Plagianthus wood from several locations by Wood and Walker (2008). These three taxa, Pittosporum tenuifolium, Pseudopanax sp., and Hoheria/Plagianthus, are striking indicators of how profoundly the vegetation in the area has changed since human settlement. Unlike Sophora, which occurs as relicts throughout the area today, these taxa are now extinct within the study area. The present study confirms that these had a definite presence through the gorges. Their importance is that where they do occur elsewhere, it is typically as a component of genuine moist forest (or at least seral in situations which clearly were moist forest). For example, to the northwest, the nearest extant $P$. tenuifolium to the study area is at the southern end of Lake Wanaka (to the southwest it would be the margins of Lake Wakatipu). There, in the Glendhu Bluff Conservation area it forms a prominent part of 
the biomass of a low forest, along with Pseudopanax, Aristotelia, Carpodetus, and Fuchsia (pers. obs.). Walker et al. (2004b) regard these species as suggesting their bioclimatic zones III or IV, normally found at significantly higher and moister sites than the lower gorges. The present study found Pittosporum tenuifolium in $27 \%$ of shelters, Pseudopanax sp. in $4 \%$, and Hoheria/Plagianthus in $5 \%$. Thus, they are seen as subordinate to Sophora, but as generally smaller trees, also contributing to the canopy.

In contrast to the forest indicators, there is a common component of other taxa in the shelters which argue for lower and more open vegetation. For example, Rubus, Muehlenbeckia, Carmichaelia, and Olearia are all locally common in the current vegetation of the study area, with Rubus and Muehlenbeckia sprawling over 'grey shrub' (Wardle, 1991) or the 'Matagouri-mingimingi shrub association' of Walker et al. (2003). Carmichaelia (native broom) species are locally common in shrubland today (although individual species may be rare) and the present study, plus the Carmichelia seeds found in two shelters by Wood and Walker (2008) indicates it was common in the mid-late Holocene, too. Like Sophora, it is another legume that is probably under-represented in palynological records, where it is usually not reported.

The 'whip-cord' Hebe cupressoides is present in numerous shelters. It was identified in $31(37 \%)$ of those in the Cromwell Gorge and in $3(12 \%)$ of shelters in the Roxburgh Gorge, but it is extinct in the study area now. The common shelter remains of Hebe cupressoides clearly support Bathgate's (1922) report that in the time of early European settlement in the Alexandra-Clyde region, the species was an "element" of the "scrub in the riverbed" (he had been forwarded some young plants from Blackstone Hill Station, about $40 \mathrm{~km}$ northeast of Alexandra). Walker et al. (2004) referred to Bathgate (1922) as an account of "Hebe cupressioides in Zone II" and noted it as a species that does not occur "in lowland Central Otago today". The present work indicates the species extended into Zone I and was in the gorges. The other Hebe found in many of the shelters, $H$. pimeleoides, remains locally common in the area, but mostly not near (within a few kilometres) of the shelters (pers. obs.).

Olearia cuticle found in the present study is not attributed to species. Wood and Walker (2008) found Olearia leaves (also not identified to species) in only one of their 15 sites, but they recorded Olearia seeds and/or wood (identified to O. avicen- niifolia, O. lineata, and 0 . odorata) in 12 sites. These species are shrubs to barely trees $(O$. odorata reaches to c. $4 \mathrm{~m}$ ), and if they were the dominant plant, as Wood and Walker (2008) conclude, the vegetation would certainly not be regarded as a 'forest'. However, the present study found Olearia in only $10 \%$ of shelters, suggesting they were subordinate to the much larger and more common Sophora.

The presence of the mistletoe Korthalsella in the shelter material is remarkable as it is very restricted today and forms a small fraction of the biomass even where it does grow. Specific identification is not regarded as possible on the material available, but different species have different preferred hosts, with some typically found growing on Leptospermum and Kunzea (occurring in large patches throughout Central Otago today, although virtually absent from the shelters). However, Korthalsella has also been reported on a few other plants, including Sophora (Stevenson, 1935; Sultan, 2014).

In the present study, the only evidence of Myrtaceae in the shelter material was two fragments of Kunzea ericoides leaf. The modern distribution of this species has been used to suggest it once had a more important presence - as extensive 'woodland' (Burrell, 1965). However, Kunzea does not figure prominently in Holocene pollen diagrams and McGlone (2001, p.10) has claimed it is a "very poorly represented pollen type",although in other situations the "Leptospermum-type" of pollen seems well-represented (Wilmshurst et al., 1997). Walker et al. (2003) modelled an important component of Kunzea in their Zones I, II, and III. However, as they were aware, this result likely reflects its present, post human-burning situation. Anthropogenic burning dates to shortly after human arrival in the late thirteenth century (Wilmshurst et al., 2008) or early fourteenth century (Jacomb et al., 2014), when there was an extremely intense burning period (McWethy et al., 2009, 2010). This replaced much forest with a highly flammable early-successional scrubland, typically involving Leptospermum and Kunzea (Perry et al., 2012). In this scenario large patches of Kunzea (and similarly Leptospermum) are anthropogenic and not an 'original' vegetation type, consistent with the rarity of Kunzea in the shelter material. Removing Kunzea from Walker et al.'s (2003) modelled vegetation types leaves Sophora as the likely main tree across all three Zones I, II, and III.

Some other plant taxa with a common presence in the peripheral region today are notably 
absent from the samples. These include conifers. In particular, Prumnopitys taxifolia, is known to have been ingested (in other areas) by all the moa species present in the study area (Wood et al., 2020). It is inconceivable that if it formed a prominent part of the vegetation near the shelters, some trace of it would not have been found in the course of this study. In light of the absence of conifer foliage, the single Podocarpus seeds recorded by Wood and Walker (2008) from the Firewood Ck and Gibraltar Rock deposits were likely bird transported from higher on the slopes. Isolated occurrences of living Podocarpus occur today on the Dunstan Mountains, including the higher slopes of the Cromwell Gorge, almost directly above the Gibraltar Rock shelter, and in the headwaters of Firewood Creek on the western side above Cromwell (pers. obs.). As per previous authors (Molloy et al. 1963; Wells, 1972. Walker et al., 2004a, 2004b), Podocarpus was clearly a prominent component of higher altitude forests (up to around 900 $\mathrm{m}$ above sea level) in pre-settlement time. The absolute absence of any conifer foliage in this study strongly suggests they did not occur on the lower slopes of the gorges. Furthermore, if conifers were not in these regions, it is very unlikely that they occurred on the exposed terraces and valley floors of the basins.

Another absence is Nothofagus. Its leaves have delicate cuticle, and it is possible that they would be lost in the dispersed cuticle process, but it is unlikely that they would not have been noticed in untreated or partially treated samples. Walker et al. (2004b) predicted a small occurrence of their biogeographic Zone IV in the Cromwell Gorge. Their model suggested Sophora as a major component of this zone, but along with the possible presence of more clearly wet forest taxa, such as Nothofagus, Griselinia and Pseudopanax. There is currently no clear evidence for Nothofagus having grown on the Dunstan Mountains, but it does persist as a few trees in the Roaring Meg Creek, marginal to the Kawarau Gorge (in biogeographic Zone IV). Griselinia has also not been found in shelter material. However, in the Waikerikeri Gorge on the eastern flanks of the Dunstan Mountains, several old, clearly relictual Griselinia trees, a single Pseudopanax and many Podocarpus are growing at about $700 \mathrm{~m}$ above sea level (pers. obs.). The location falls within Walker et al.'s. (2004b) biogeographic Zone VII and is consistent with their prediction of diverse forests at such higher and more moist altitudes. In some regions peripheral to the present study area (e.g., on the shores of Lake
Wakatipu and Lake Wanaka) low forests in which Griselinia is prominent are likely to be seral following the clearance of Nothofagus-dominated forests by fire. In that context, the relict trees of Griselinia in the Waikerikeri Gorge might be hinting at the previous presence of a Nothofagus forest, but still at a higher altitude and wetter location than any of the shelter locations.

To summarise, the present study finds evidence for a Sophora microphylla-dominated vegetation through the lower slopes of the Kawarau, Cromwell, and Roxburgh Gorges, as well as the lower slopes of the Old Man Range that would be predicted from the relict occurrence of Sophora today. Structurally, it was probably a low forest. A range of angiosperms were subordinate, including Olearia, Pseudopanax, Pittosporum tenuifolium, and Plagianthus, and/or Hoheria, but conifers were absent. The importance of Sophora agrees with that of Walker et al. $(2003,2004 b)$ if the modeled importance of Kunzea is ignored. The vegetation does not fit well with any of the types proposed by Rogers et al. (2005). Their 'Dry angiosperm shrubland -low forest' specifically only includes the Sophora species S. prostrata, while their 'Dry hardwood forest' includes 'kowhai', species not stated, but in any case, also includes conifers. The widespread presence of a vegetation without conifers is not reconcilable with models predicting coniferdominated vegetation extending right across Central Otago (Hall and McGlone, 2006; McGlone et al., 2017). Leathwick et al. (2012) clarifies that the reason for their treeless core in Central Otago was largely due to extreme minimum temperatures. Relict Sophora trees make it clear that trees, at least to $14 \mathrm{~m}$ high, can survive in parts of the region they mapped as 'Scrub, shrubland and tussock-grassland below treeline'.

\section{Moa Diet and Ecology}

In the nineteeth century it was often assumed that moas were a grassland bird - as their remains were often found in what is now tussock grassland. However, later, particularly based on the study of intact gizzard contents (Burrows, 1980a, 1980b; 1989; Burrows et al., 1981) there was a shift to understanding that moas, or at least some species, were forest or forest-margin dwellers, and that tree-browse was an important part of their diet. Like gizzard contents, the contents of coprolites provide direct evidence of what moa ate. From a shelter near the edge of Lake Wakatipu, to the west of the current study area, Wood et al. (2012) illustrated cuticle of Myrsine and a podocarp (which 
I regard as Prumnopitys taxifiolia) from a moa coprolite. In a wet, forested region even further west, Horrocks et al. (2004) documented branchlets of Nothofagus, as well as grasses, sedges and herbs, and even an apparent phylloclade of the conifer Phyllocladus from moa coprolites. These, and other studies (e.g., Wood and Wilmshurst, 2013; Wood et al., 2013; Boast et al., 2018, based on vegetative remains, pollen, or DNA), support the understanding that moas were browsers or at least, generalists. However, Wood et al. (2008) focussed on seed content of moa coprolites and claimed it "reveals a diverse diet of herbs and low shrubs in both semi-arid and high rainfall ecological zones, overturning previous models of moa as dominantly browsers of trees and shrubs." Their study included 35 coprolites from Central Otago, from which three species of leaf were recognised (Coprosma, Leucopogon and possibly Olearia), but nine genera represented by seeds.

The present study located leaf fragments in all prepared coprolites, but in every case these were very small (sub-millimetre), and very rare amongst the dominant mass of woody material and fine mineral matter. Despite this, largest coprolites, those regarded as moa, contain vegetative fragments of Carmichaelia sp., Hebe cupressoides, Korthalsella sp., Muehlenbeckia sp., Myrsine divaricata, Olearia sp., Pittosporum tennuifolium, Poaceae, Pseudopanax ferox, Rubus sp., and Sophora microphylla. That is, they contain a subset of the plants found in the dry vegetation zone, and it's likely that continued study would find the rest. The cuticle results support Wood et al.'s (2012) cuticle record of Myrsine consumption and of mistletoes (Wood et al., 2020, 2021). It also confirms the suggestion of Wood and Wilmshurst (2013) that based on the presence of its pollen in coprolites, Carmichaelia was probably directly consumed by the moa. However, prior to the current study, neither Sophora pollen nor leaf material had been recorded from moa coprolites (Wood et al., 2008a; Wood and Wilmshurst, 2013, 2014; Wood et al., 2012). In fact, Wood et al. (2020) cite Sophora as a plant, which appeared to have been actually avoided by moa. In the present study, of 36 processed coprolites, Sophora was found in 19. Of these, Sophora was present in eight of the 16 largest coprolites that were considered as clearly moa. These occurred in six separate shelters. For some of these coprolites, Sophora was the only leaf material found within them. For others, it was one of only three taxa. Taking the evidence at face value, Sophora was an important dietary component in what was depositing these largest coprolites which were, beyond any reasonable doubt, moa. The conclusion that moa consumed Sophora is thus novel but may sound surprising. As a legume, Sophora has nitrogen-rich foliage, and in that respect, it might be expected to be an important source of nutrients for birds. However, Sophora is regarded as a poisonous plant in New Zealand (Connor, 1977; Slaughter, et al., 2012). Despite this, its leaves are eaten by some extant New Zealand birds, such as the indigenous pigeon (McEwen, 1978), and the foliage and twigs are "palatable" to some introduced mammals (Batcheler, 1989), so there are extant precedents for eating Sophora.

Given that moa did consume Sophora, and apparently inhabited Sophora-dominant vegetation, one might ask if there was a connection. In New Zealand, Sophora is also well known to horticulturalists as generally requiring scarification for a good germination rate. Webb (1993) noted scarification was possible by abrasion in river alluvium (lake-edge situations with wave-wash on gravel probably also achieves this - pers. obs.), but possibly also occurred by microbial action on buried seeds. He also found that fire had a very negative effect on germination. Thus, there is no question that Sophora can regenerate in the wild today, but was this enough to maintain an extensive Sophoradominated ecosystem, mostly well-away from river and lake margins? Could moa gizzards (which contained crop-stones) have been an effective, widespread scarification agent? Webb (1993) suggested it was possible but noted that the evidence of Sophora seeds in intact gizzard contents was lacking, and this remains the case. The broader question as to whether moa distributed larger seeds was investigated by Carpenter et al. (2018). Their study found that the only seeds which survived passage through the moa gizzards were less than $3.3 \mathrm{~mm}$ long (around half that of Sophora microphylla). Any larger seeds appear to have been destroyed. This would suggest that moa did not disperse Sophora seeds by ingestion. However, given the current understanding that the dried vegetation in the rock shelters was brought in by moas, and perhaps other birds (doubtless some material would have blown in), the fact that Sophora seeds are inside shelters at all (Wood and Walker, 2008) suggests moa were distributing them in a direct sense (i.e., as pods attached to foliage, rather than gizzard-content). But while Sophora microphylla seeds may not normally have passed intact through a moa gut, the few that did 
might have been important. Like the discovery of Sophora leaf fragments, a closer look at the coprolites may yet turn up their seeds (the Carpenter et al., 2018 study only involved four coprolites from the Central Otago drylands where Sophora would have been prominent).

As concluded by Wood and Walker (2008) most of the vegetative material in the shelters was probably introduced by birds. However, although these shelters are sometimes referred to as "moa nests", this suggestion is rejected here, for the simple reason that moa eggshell is vanishingly rare in the shelters. Out of 115 shelters, only four (Shelters $18,44,45,51$ ) had moa eggshell, and in all cases, this was only $1-3$ small (c. $10 \mathrm{~mm}$ ) pieces, mainly dug up by rabbit activity (the observation of no or little eggshell is not based on samples. Rather, in most shelters there is an enormous amount of floor-fill material dug up by rabbits, making the absence of eggshell obvious). The enormous size of moa eggs (Worthy and Holdaway, 2002) means that even a single egg would have produced many hundreds of fragments, let alone what would accumulate over centuries of use in nesting sites. Even if moa engaged in activities such as periodically scraping eggshell out (eggshell removal by nesting birds is a known phenomenon, Arnold, 1992, but would also remove the vegetation), or even ingesting eggshell, such behaviour would not have removed virtually all trace. On that basis, it is more likely that the shelters were roosting areas (as also suggested by Wood and Walker, 2008). Moa eggshell fragments are locally common over the broader region (pers. obs.) in deep, soft sediment, such as windblown sand, and nesting was probably in these locations where nesting burrows could be scooped.

DNA work will eventually confirm the depositing species, and probably identify the presence of other plant species in those coprolites. However, in this context, some caution is warranted. A recent paper (Wood et al., 2021) investigated moa coprolites and identified their content based on DNA and cuticle. A major claim of the paper was that ferns were "an important part of their diet". The paper includes figures of six cuticle types, which were identified by comparing them with a previously existing series of (unscaled) photographs. However, their figure of "fern (cf. Blechnaceae", Wood et al., 2021, fig. 6K), is clearly not fern (fern cuticle is not remotely robust enough to form buttresses) but is the adaxial cuticle of the conifer Prumnopitys taxifolia. Their Lophozonia menziesii-type cuticle (Wood et al., 2021, fig. 6E) is not Lophozonia (the subsidiary cells are not distinctly smaller than the guard cell pair. But what the taxon is, is unclear, as the image is mostly out of focus, perhaps a Metrosideros). More interesting is their figure $6 \mathrm{l}$, which, rather than being "Araliaceae (Pseudopanax-type cuticle)", is a podocarp conifer. But the important point is that it is neither of the podocarps (Dacrydium and Prumnopitys) identified in the coprolite using 'plant DNA metabarcoding', but most likely a Halocarpus (based on the very round stomatal complex and very broad polar subsidiary cells). Thus, while DNA techniques are clearly an enormous breakthrough, cross-referencing checks between results from them and microscopic technique remain important.

\section{Mid-Late Holocene Vegetation Change}

A general observation was that all 'productive' shelters are restricted to low altitude, within about $100 \mathrm{~m}$ above river/lake level in or near the gorges, and likely also restricted to zones of more massive schist. Higher regions were surveyed, and though there are many schist rock outcrops there, they either tend not have overhangs, or had no accumulated sediment. These higher altitude shelters may be damper and/or may receive less wind-blown material than lower ones making them less likely to preserve plant matter. There are numerous morphologically 'good' shelters that are south-facing, but with no vegetation accumulation in them, probably because they remain slightly damp in the winter. There is a notable restriction of dry vegetation accumulations to exceptionally dry shelters mostly, although not entirely, north to north-east facing, as recorded by Wood and Wilmshurst (2014). This draws attention to an observation made by Wood et al. (2008), that dated shelter materials are restricted to c. $<4000$ BP (an exception is the early Holocene site of Gibraltar Rock, McGlone, and Wood, 2019). Wood et al. (2008) proposed that mid-late Holocene climatic change may have made conditions dry enough that shelter material began to survive. They related this to an apparent "mid-Holocene aridification of the Central Otago region" attributed to McGlone and Moar (1998). However, McGlone and Moar (1998) had concluded that there was a "gradual onset of wetter, cooler climates" over the Holocene in southern New Zealand (e.g., McGlone and Bathgate, 1983) but with evidence that summer droughts may have increased in Central Otago from c. 5000 BP. Later work (Wilmshurst et al., 2002) modified this hypothesis in favour of cooler winters and drier summers. A potential problem with that initiating 
shelter accumulations is that relatively moist winter conditions would remain as a weak link. The general absence of dry vegetation in south-facing shelters or at higher altitude, is an indication of just how dry they must remain for the vegetation to preserve. However, if summers earlier in the Holocene were less drought-ridden, then it might be inferred that vegetation at the time may have been different - perhaps taller and denser. Within such vegetation, even north-facing shelters might have remained damp enough throughout the year to inhibit the accumulation of vegetation inside them. In other words, increased summer drought may have resulted in the elimination of taller, more closed forest (either by being too dry for the canopy trees to regenerate, or their removal by a fire).

In this respect, McGlone and Moar's (1998, p. 97) palynological documentation of a dryland site at Idaburn, c.7500 -4000 BP is relevant. They noted that pollen of the conifer Prumnopitys taxifolia was dominant (up to c. $20 \%$ ) but interpreted the local vegetation as "a mosaic of small leaved scrubland, .... and low tussock grassland". They interpreted the pollen of Prumnopitys and other conifers, such as Dacrycarpus and Podocarpus, as coming from "stands outside the Idaburn valley region, as there is no other evidence for these podocarps ever having grown in this semi-arid area", and that (p. 109) there were "stands of these trees in Central Otago, perhaps on the slopes of wetter mountains, but not in the Idaburn Valley or on the adjacent dry ranges." Podocarpus pollen formed about $5-10 \%$ of their totals, and they cited Pocknall's (1982) work on modern pollen rain that Podocarpus laetus (the most likely source of the Idaburn pollen) as being "severely" under-represented, and therefore the parent trees likely grew "nearby". However, in another study on modern pollen rain, Pocknall (1978) found that Dacrycarpus and Prumnopitys taxifolia are also under-represented. If all these under-represented taxa were blowing in prominent amounts into the Idaburn site from wetter areas outside the region, it begs the question of why local and better-represented taxa, are not common in their samples. An explanation is that Prumnopitys forest was nearby. The replacement of such a forest with a Sophora-dominated one in response to drier summers, or a fire (e.g., the fire which may have removed Prumnopitys from the Old Man Range c. 2400 BP, McGlone, 1995) may have provided the more open and drier conditions conducive to vegetation accumulation in the shelters. In contrast, the recent documentation of a (there appear to be more than one) Gibraltar
Rock shelter (McGlone and Wood, 2019) argued for even drier conditions than now in the early Holocene, and low, shrubby vegetation. However, because of its under-representation, their $7.8 \%$ Sophora pollen is likely to be indicating a considerable actual presence of Sophora, consistent with the other shelters. The material was identified as coming from the shrub $S$. prostrata, rather than $S$. microphylla. However, S. prostrata does not grow in the Central Otago region today (Metcalf, 1972) in the absence of evidence for why this identification was made, it is unconvincing.

\section{An Extinct Ecosystem}

The gorges and lower slopes of Central Otago had a Sophora microphylla-dominant vegetation. The remarkably ubiquitous combination of plant taxa that occur repeatedly throughout the Central Otago mid-late Holocene shelters suggests the vegetation extended from at least the upper Roxburgh Gorge in the south-east to at least the NevisKawarau junction in the north-west and grew across a range of Walker et al.'s (2004b) bioclimatic zones (mostly I, II, and III, and one in Zone IV). This vegetation was inhabited by and consumed by, several species of moa, as well as other birdlife either fully extinct, or no longer present in the area (Worthy, 1998). In an analysis of the distribution of moa species across New Zealand Worthy (1990, p. 221) proposed that the structure of "vegetation types is all important in determining the suitability or otherwise to one or other moa species" and "to a certain extent the specific composition of the vegetation types is secondary." Of relevance here, one species, Megalapteryx didinus, was prominent in inland South Island assemblages, though typically in higher altitudes. Others, like Euryapteryx geranoides and Pachyornis elephantopus tended to be prominent in the relatively drier country east of the Main Divide. Coming to an understanding of the structure of Central Otago's mid-late Holocene vegetation is therefore important to further refine what lay behind moa ecological niches. Given the apparent importance of structure, the distinction between shrubland and forest is clearly critical, and if it was forest, where it lay on the open-closed spectrum. Future work might relate some moa species more closely to the Sophora-dominant vegetation.

The Sophora-dominant vegetation developed in an essentially fire-free environment. Although palynology and soil charcoals make it clear that fires did burn there throughout the mid-late Holocene (Clark et al., 1996; McGlone et al., 1995), 
there were likely areas where fire was entirely absent (McGlone, 2001). Where fires did occur, it appears that they had such long return intervals, that pre-existing vegetation typically grew back (Rogers et al., 2005), and as these authors emphasized, fires were not frequent enough to maintain extensive grasslands. However, evidence remains that even rare fire events may have had permanent effects (McGlone 1995). The enormous fires that occurred shortly after humans arrived removed a huge proportion of forest in New Zealand (McWethy et al., 2009, 2010; Perry et al. 2012) and were likely behind most of the destruction of the Sophora ecosystem. Although not a goal of this study, macroscopic charcoal (> c. $0.5 \mathrm{~mm}$ ) was not noted within intact accumulations of dry vegetation in the shelters. However, in the field it was sometimes noted that the uppermost layer of dry vegetation was charred. This is consistent with it being a generally fire-free environment earlier into which a late phase fire (i.e., the human period) had burned into the shelter.

As a vegetation type, the Sophora-dominant forest appears now to be extinct. While the specific components of the vegetation still survive either within, or out of the region, the assemblage has been 'atomized'. In a few small spots, there are clusters of Sophora microphylla, but the individuals are not close enough to form a canopy (the larger trees are typically restricted to widely separated fire-protecting rock crevasses), and they occur without Hebe cupressoides, Pittosporum, and Pseudopanax. Relict Hebe cupressoides remain in a very few places (outside the study area) - but without any Sophora, Pittosporum and Pseudopanax, and so-on. As a vegetation type, we have no idea how all the species of the Sophora forest were placed in a structural sense, or how they interacted over long periods of no fire. It can be surmised that Pittosporum, Pseudopanax, and Fuchsia/Plagianthus were scattered between the Sophora and contributed to a relatively closed canopy. These species are all forest trees in various places of New Zealand today. But what to make of the Olearia, whip-cord Hebe and Carmichaelia? Today these are more definitively restricted to shrubland, or at least, 'non-forest'. But is this an artifact of burning? One interpretation might say that these more open-vegetation plants persisted throughout the Sophora-forest, but on patches of shallower soils and rocky areas. However, taking the shelter material at face value, another interpretation could be that these species were all thoroughly mixed. Perhaps Olearia, whip-cord Hebe and Carmichae- lia are shade-tolerant enough to reproduce below a Sophora canopy, and particularly one modified by moa activity. Or perhaps they regenerated in moainduced gaps and were later overtopped by Sophora. These questions are probably only answerable by re-creating the assemblage (and waiting several centuries!). A useful analogue of the Sophora-dominated plant association of Central Otago might exist in Hawaii, where Sophora (S. chrysophylla [Salisbury] Seemann, 1865) is a dominant component of a low, dry forest. The flowers, flower buds, foliage flush, and seeds of S. chrysophylla are an important food for the finch Loxioides bailleui (van Riper, 1980a, 1980b; Hess et al., 1999). However, the extent of this dry forest has significantly declined, with one of the issues being the "scarcity" of its regeneration (Scowcroft, 1982). For horticultural purposes, the seeds of S. chrysophylla require scarification for successful propagation, without which germination rates are less than 5\% (Obata, 1967), although more successful rates in the wild have been reported (Scowcroft, 1982; Hess et al., 1999). This does beg the question as to whether a species that consumes the seeds, i.e., the finch, possibly like the moa, may be a natural scarification agent.

Central Otago may be unique as having been the last relatively dry place on Earth to remain human-free. It has much to teach us about what kind of vegetation can exist in such environments. Human impact has not only caused the destruction of this ecosystem but introduced animals appearing to be destroying even the evidence that it existed. The current study noted that several Holocene shelter accumulations were restricted to a remnant 'piedmont' of sediment - which remained after surrounding material had been thoroughly dug over by rabbit burrowing. In addition, some otherwise 'perfect' shelters (size, aspect) were encountered, but which were floored with bare, or mostly bare rock. These piedmonts are probably a transitional stage to the barren, rock-floored shelters and suggest that there is a conservation issue to consider. The important record of Central Otago's extinct ecosystem is slowly vanishing.

\section{CONCLUSIONS}

The results of this study confirm those of earlier ones that there was a much more highly vegetated landscape in mid-late Holocene, pre-human times in the lowlands of Central Otago. The present study emphasizes the importance of Sophora microphylla, which is proposed to have been the major component of a low forest, occurring in the 
lower altitudes of the gorges of the study area. It was associated with other small trees, including Pittosporum tennuifolium and Pseudopanax ferox. However, there is a constant association with smaller plants which suggest more open vegetation, such as Carmichaelia and the 'whipcord' Hebe cupressoides. Whether these grew throughout the low Sophora-dominated forest or as distinct patches of shrublands is not clear. Olearia does not appear to have been prominent, and there is no evidence of any Nothofagus or conifers in these dry zones. The suggestion is made that such vegetation may have existed earlier, perhaps with important Prumnopitys taxifolia. The replacement of this vegetation by a more open forest may have provided the drier conditions which allowed the shelter deposits to accumulate.

The rock shelters in the study area were likely used by moa as roosting shelters. The present study highlights the importance of Sophora microphylla, not just as the regional vegetation dominant, but as a component of moa diet. That is, moa browsed on Sophora trees and may have been a key ecological component of Sophora-based vegetation.

\section{Why This Matters and Future Research}

A recent podcast produced by New Zealand's national radio station (Radio New Zealand, 2021) features an interview with University of Otago Botany $\mathrm{PhD}$ student Ben Teele. His research is focused on mapping the remnant populations of Podocarpus laetus (thin-barked tōtara) on the mountain slopes in Central Otago. The research is funded by the government, as part of a broader long-term tree-planting project, where, as the podcast narrator Claire Concannon puts it, "planting the right tree in the right place", is important. As they walk up the Dunstan Range (which forms the north-eastern side of the Cromwell Gorge), Teele remarks (at 01:35) "think of all the tussock and shrubland ... in Central ... and replace it with tōtara". Having just passed a patch of relict Sophora microphylla on a fire-protected spot, Teele also says (at 07:07) "If we go back a thousand years ... we would be standing in tōtara forest, all the way down to the flats of classic Central Otago". This view appears to have its basis in the "cool dry podocarp' forest prediction of Hall and McGlone (2006). I mention this interview because it gives an excellent introduction to why the results of Holocene paleobotany and vegetation modelling now have additional relevance, but also because it illustrates how one debateable hypothesis has risen to where it is broadcast on national radio. Given that relict podocarps, like tōtara, are restricted to relatively high altitudes, and Sophora to low altitudes (there is essentially no overlap in Central Otago), precisely how Sophora was 'disappeared' and 'replaced' with conifers in several narratives is perplexing. Hall and McGlone (2006) blamed the absence of conifers at lower altitudes predicted in Walker et al.'s (2004b) model as it was based on heavily fire-modified vegetation. However, a reasonable assumption is that this implies the abundance of Sophora predicted by Walker et al. (2004b), is also a result of fire - which it clearly isn't. Why Sophora was demoted from its importance in Walker et al. (2004ab) to a no-mention in Wood and Walker (2008) is equally perplexing. One has to assume that the numbers of the (typically smaller and more mass-produced) Coprosma-Olearia-Corokia shrub-small tree seeds were given more weight than the larger Sophora tree seeds, and that, for example, the six shelters Olearia seeds were found in, were more important than the five that had Sophora.

In the present study, repeated samples have failed to turn up a single trace of any conifer leaf, despite conifers being asserted to have been the dominant plant by Hall and McGlone (2006). This surely means something, and I would have thought it was compelling evidence of no significant conifers in the area. However, an anonymous reviewer of this manuscript urged that all discussion of this 'absence of evidence' be deleted. This would, of course, have the effect of shielding the coniferdominance model from criticism, as no amount of further lack of actual specimens will make any difference.

I suggest that the onus is now on proponents of the conifer-dominance hypothesis to convincingly argue for the lack of presence in shelters, and the onus is also on those who don't see Sophora microphylla, the only large tree in the area, to explain why it wasn't playing a major, and probably the major, role in the Central Otago gorges, in prehuman times.

\section{ACKNOWLEDGEMENTS}

I thank 'Miss Annan' of the Clyde Museum, who, when I was a schoolboy in the 1970s, first encouraged me to start looking at Holocene material in the Cromwell Gorge. Around the same time, one of my teachers, P. Child, pointed me up the Waikerikeri Valley to look at relict vegetation. Thanks to A. Evans of Dunedin Botanical Garden and J. Ladley, University of Canterbury, for com- 
parative material. I am grateful to the owners of Cairnmuir Station (A. Hamilton), Earnscleugh Station (firstly M. Mulvena, then A. Campbell), Little Valley Station (N. Saunders), Northburn Station (T. Pinckney), Wentworth Station (A. May), and Kawarau Station (J. Anderson) for access. Thanks also to S. Collins, G. Mason, B. Walker, B. Nagle,
D. Pillai, M. Marra, and others in the tree planting groups for discussion on Central Otago's pre-European vegetation. The comments of three anonymous reviewers greatly improved the manuscript. The work would not be possible without the continuing support of $\mathrm{V}$. Leung.

\section{REFERENCES}

Aiton, W. 1789. Hortus Kewensis 2. George Nicol, London.

Albach, D.C. and Chase, M.W. 2001. Paraphyly of Veronica (Veroniceae; Scrophulariaceae): evidence from the internal transcribed spacer (ITS) sequences of nuclear ribosomal DNA. Journal of Plant Research, 114:9-18. https://doi.org/10.1007/pl00013971

Albach, D.C., Martínez-Ortega, M.M., Fischer, M.A., and Chase, M.W. 2004. A new classification of the tribe Veroniceae - problems and a possible solution. Taxon, 53:429-452. https://doi.org/10.2307/4135620

Angiosperm Phylogeny Group, 2016. An update of the Angiosperm Phylogeny Group classification for the orders and families of flowering plants: APG IV. Botanical Journal of the Linnean Society, 181:1-20. https://doi.org/10.1111/boj.12385

Arnold, T.W. 1992. The adaptive significance of eggshell removal by nesting birds: Testing the egg-capping hypothesis. Condor, 94:547-548. https://doi.org/10.2307/1369232

Atkinson, I.A.E. 1985. Derivation of vegetation mapping units for an ecological survey of Tongariro National Park, North Island, New Zealand. New Zealand Journal of Botany, 23:361-378. https://doi.org/10.1080/0028825x.1985.10425343

Banks, J. and Solander, D.C. 1788. p. 286. In Gaertner, J. De Fructibus et Seminibus Plantarum, vol 1. Stutgart, Typis Academiae Carolinae.

Barnhart, J.H. 1895. Family nomenclature. Bulletin of the Torrey Botanical Club, 22:1-24. https:// doi.org/10.2307/2485402

Batcheler, C.I. 1989. Moa browsing and vegetation formations, with particular reference to deciduous and poisonous plants. New Zealand Journal of Ecology, 12:57-65.

Bathgate, A.1922. Some changes in the fauna and flora of Otago in the last 60 years. New Zealand Journal of Science and Technology, 4:273-283.

Batsch, A.J.G.K. 1794. Synopsis Universalis Analytica Generum Plantarum Fere Omnium Hucusque Cognitorum, Pt 2. Sumtibus Bibliopolii Croekeriani, Jena.

Batsch, A.J.G.K. 1802. 'Violariae'. Tabula affinitatum regni vegetabilis, quam delineavit, et nunc ulterius adumbratam (in Latin). Landes-Industrie-Comptoir, Weimar.

Bayly, M. and Kellow, A. 2006. An Illustrated Guide to New Zealand Hebes. Te Papa Press, Wellington.

Berchtold, B.V. von and Presl, J.S. 1820. O Prirozenosti Rostlin aneb Rostlinář. K.W. Enders, Prague.

Boast, A.P., Weyrich, L.S., Wood, J.R., Metcalf, J., Knight, R., and Cooper, A. 2018. Coprolites reveal ecological interactions lost with the extinction of New Zealand birds. Proceedings of the National Academy of Sciences USA, 115:1546-1551. https://doi.org/10.1073/pnas.1712337115

Breitwieser I., Brownsey P.J., Heenan P.B., Nelson W.A., and Wilton A.D. (eds.) 2010. Flora of New Zealand Online. Accessed at https://www.nzflora.info/.

Brown, R. 1814. p. 542. In Flinders, M.A. Voyage to Terra Australis, 2. G. and W. Nicol, Pall-Mall.

Brown, R. 1825. Carmichaelia australis. South-sea Carmichaelia. Botanical register. Botanical Register, 11:912-913.

Buchanan, J. 1884. Notes on new species of plants. Transactions and Proceedings of the New Zealand Institute, 16: 394-396.

Burrell, J. 1965. Ecology of Leptospermum in Otago. New Zealand Journal of Botany, 3:3-16. https://doi.org/10.1080/0028825x.1965.10428708

Burrows, C.J. 1980a. Diet of New Zealand Dinornithiformes. Naturwissenschaften, 67: 151-153. 
Burrows, C.J. 1980b. Some empirical information concerning the diet of moas. New Zealand Journal of Ecology, 3:125-130.

Burrows, C.J. 1989. Moa browsing: evidence from the Pyramid Valley mire. New Zealand Journal of Ecology, 12 (supplement):51-56.

Burrows, C.J., McCulloch, B.J., and Trotter, M.M. 1981. The diet of moas based on gizzard contents samples from Pyramid Valley, North Canterbury and Scaifes Lagoon, Lake Wanaka, Otago. Records of the Canterbury Museum, 9:309-336.

Carpenter, J.K., Wood, J.R., Wilmshurst, J.M., and Kelly, D. 2018. An avian seed dispersal paradox: New Zealand's extinct megafaunal birds did not disperse large seeds. Proceedings of the Royal Society, B 285:20180352. https://doi.org/10.1098/rspb.2018.0352

Clark, G.R., Petchey, P., McGlone, M.S., and Bristow, P. 1996. Faunal and floral remains from Earnscleugh Cave, Central Otago, New Zealand. Journal of the Royal Society of New Zealand, 26:363-380. https://doi.org/10.1080/03014223.1996.9517515

Cockayne, L.C. 1910. Some hitherto unrecorded plant habitats (VI). Transactions of the New Zealand Institute, 43:169-174.

Cockayne, L.C. and Allan, H.H.B. 1927. The present taxonomic status of the New Zealand species of Hebe. Transactions of the New Zealand Institute, 57:11-47.

Connor, H.E. 1977. The poisonous plants in New Zealand. Government Printer, Wellington.

Connor, H.E. and Edgar, E. 1987. Name changes in the indigenous New Zealand flora, 19601986 and Nomina Nova IV, 1983-1986. New Zealand Journal of Botany, 25:115-170. https://doi.org/10.1080/0028825x.1987.10409961

Cox, J.E. and Mead, C.B. 1963. Soil evidence relating to post-glacial climate on the Canterbury Plains. Proceedings of the New Zealand Ecological Society, 10:28-38.

Cunningham, A. 1839a. Florae insularum Novae Zelandiae precursor; or a specimen of the botany of the islands of New Zealand. Annals of Natural History, 3:244-250.

Cunningham, A. 1839b. Florae insularum Novae Zelandiae precursor; or a specimen of the botany of the islands of New Zealand. Annals of Natural History, 2:44-52.

Cunningham, A. 1839c. Florae insularum Novae Zelandiae precursor; or a specimen of the botany of the islands of New Zealand. Annals of Natural History, 2:125-132.

Dilcher, D.L. 1974. Approaches to the identification of angiosperm leaf remains. The Botanical Review, 40:1-157. https://doi.org/10.1007/bf02860067

Forster, J.R. and Forster, J.G.A. 1776. Characteres generum plantarum, quas in itinere ad insulas maris australis, collegerunt, descripserunt, delinearunt, annis MDCCLXXIIMDCCLXXV. White, Cadell, and Elmsley, London.

Garnock-Jones, P., Albach, D., and Briggs, B.G. 2007. Botanical names in Southern Hemisphere Veronica (Plantaginaceae): sect. Detzneria, sect. Hebe, and sect. Labiatoides. Taxon, 56:571-582. https://doi.org/10.1002/tax.562028

Hall, G.M.J. and McGlone, M. 2006. Potential forest cover of New Zealand as determined by an ecosystem process mode. New Zealand Journal of Botany, 44:211-232. https://doi.org/10.1080/0028825x.2006.9513019

Heenan, P.B. 1998. An emended circumscription of Carmichaelia, with new combinations, a key, and notes on hybrids. New Zealand Journal of Botany, 36:53-63. https://doi.org/10.1080/ 0028825x.1998.9512546

Heenan, P.B., de Lange, P.J., and Wilton, A.D. 2001. Sophora (Fabaceae) in New Zealand: Taxonomy, distribution, and biogeography. New Zealand Journal of Botany, 39:17-53. https://doi.org/10.11646/phytotaxa.146.1.1

Heenan, P.B. and Smissen, R.D. 2013. Revised circumscription of Nothofagus and recognition of the segregate genera Fuscospora, Lophozonia, and Trisyngyne (Nothofagaceae). Phytotaxa, 146:1-31. https://doi.org/10.11646/phytotaxa.11146.11641.11641

Heenan, P., Mitchell, C., and Houliston, G. 2018. Genetic variation and hybridisation among eight Species of kōwhai (Sophora: Fabaceae) from New Zealand revealed by microsatellite markers. Genes, 9:111. https://doi.org/10.3390/genes9020111

Hess, S.C., Banko, P.C., Brenner, G.J., and Jacobi, J.D. 1999. Factors related to the recovery of subalpine woodland on Mauna Kea, Hawaii. Biotropica, 31:212-219. https://doi.org/10.1111/ j.1744-7429.1999.tb00133.x

Holdaway, R.N. 1989. New Zealand's pre-human avifauna and its vulnerability. New Zealand Journal of Ecology, 12:11-25. 
Horrocks, M., D'Costa, D., Wallace, R., Gardner, R., and Kondo, R. 2004. Plant remains in coprolites: diet of a subalpine moa (Dinornithiformes) from southern New Zealand. Emu, 104:149-156. http://doi.org/10.1016/j.revpalbo.2007.12.009

Horrocks, M., Salter, J., Braggins, J., Nichol, S., Moorhouse, R., and Elliott, G. 2008. Plant microfossil analysis of coprolites of the critically endangered kakapo (Strigops habroptilus) parrot from New Zealand. Review of Palaeobotany and Palynology, 149:229-245. https://doi:10.1016/j.revpalbo.2007.12.009

Hubbard, J.C.E. and Wilson, J.B. 1988. A survey of the lowland vegetation of the Upper Clutha District of Otago, New Zealand. New Zealand of Botany, 26:21-35. https://doi.org/10.1080/0028825x.1988.10410097

Jacomb, C., Holdaway, R.N., Allentoft, M.E., Bunce, M., Oskam, C.L., Walter R., and Brooks, E. 2014. High-precision dating and ancient DNA profiling of moa (Aves: Dinornithiformes) eggshell documents a complex feature at Wairau Bar and refines the chronology of New Zealand settlement by Polynesians. Journal of Archaeological Science, 50:24-30.

Jussieu, A.L. de 1789. Genera Plantarum. Herissant et Theophilum Barrois, Paris.

Jussieu, A.L. de 1808. Huitème mémoire, Sur les caractères familles tires des grains, et confirmés ou rectifies par les observations de Gærtner, et spécialement sur les Caprifoliées et la famille nouvelle des Loranthées. Annales du Muséum national d'histoire naturelle, 12:285-303

Kirk, T. 1889. The Forest Flora of New Zealand. Government Printer, Wellington.

Koch, C. 1859. Araliaceae. Wochenschrift für Gärtnerei und Pflanzenkunde, 2:354-372.

Leathwick, J.R., McGlone, M.S., and Walker, S. 2004. New Zealand's potential vegetation pattern. Poster, Manaaki Whenua Press, Lincoln, New Zealand.

Leathwick, J., McGlone, M., and Walker, S. 2012. Documentation for 'New Zealand's potential vegetation pattern'. Landcare Research. https://Iris.scinfo.org.nz/document/9292-new-zealands-potential-vegetation-pattern/

Lindley, J. 1836. Natural System of Botany: or, a Systematic View of the Organization, Natural Affinities, and Geographical Distribution of the Whole Vegetable Kingdom Together with the Uses of the Most Important Species in Medicine, the Arts, and Rural and Domestic Economy. Edition 2. Longman, Rees, Orme, Brown, Green, and Longman, London. https://doi.org/10.5962/bhl.title.130142

Linnaeus, C. 1753. Species Plantarum 1. Laurentius Salvius, Stockholm.

Macara, G.R. 2015. The Climate and Weather of Otago. Second Edition. NIWA Science and Technology Series, 67. NIWA Taihoro Nukurangi, Auckland.

McEwen, W.M. 1978. The food of the New Zealand pigeon (Hemiphaga novaeseelandiae novaeseelandiae). New Zealand Journal of Ecology, 1:99-108.

McGlone, M.S. 2001. The origin of the indigenous grasslands of southeastern South Island in relation to pre-human woody ecosystems. New Zealand Journal of Ecology, 25:1-15.

McGlone, M.S. and Bathgate, J.L. 1983. Vegetation and climate history of the Longwood Range, South Island, New Zealand 12,000 B.P. to the present. New Zealand Journal of Botany, 21:293-315. https://doi.org/10.1080/0028825x.1983.10428560

McGlone, M.S. and Moar, N.T. 1998. Dryland Holocene vegetation history of Central Otago and Mackenzie Basin, South Island, New Zealand. New Zealand Journal of Botany, 36:91-111. https://doi.org/10.1080/0028825x.1998.9512549

McGlone, M.S. and Wood, J.R. 2019. Early Holocene plant remains from the Cromwell Gorge, Central Otago, New Zealand. New Zealand Journal of Ecology, 43:3363. https://doi.org/10.20417/nzjecol.43.13

McGlone, M.S., Mark, A.F., and Bell, D. 1995. Late Pleistocene and Holocene vegetation history, Central Otago, South Island, New Zealand. Journal of the Royal Society of New Zealand, 25:1-22. https://doi.org/10.1080/03014223.1995.9517480

McGlone, M.S., Richardson, S.J., Burge, O.R., Perry, G.L.W., and Wilmshurst, J.M. 2017. Palynology and the ecology of the New Zealand conifers. Frontiers in Earth Science, 5: Article 94. https://doi.org/10.3389/feart.2017.00094

McWethy, D.B., Whitlock, C., Wilmshurst, J.M., McGlone, M.S., and Li, X. 2009. Rapid deforestation of South Island, New Zealand, by early Polynesian fires. The Holocene, 19:883-897. https://doi.org/10.1177/0959683609336563 
McWethy, D.B., Whitlock, C., Wilmshurst, J.M., McGlone, M.S., Fromont, M., Li, X., Dieffenbacher-Krall, A., Hobbs, W.O., Fritz, S.C., and Cook, E.R. 2010. Rapid landscape transformation in South Island, New Zealand, following initial Polynesian settlement. Proceedings of the National Academy of Sciences of the United States of America, 107:21343-21348. https://doi.org/10.1073/pnas.1011801107

Meisner, C.D.F. 1841. Plantarum Vascularium Genera. Vol. 2. Lipsiae, Libraria Weidmannia.

Metcalf, L.J. 1972. The Cultivation of New Zealand Trees and Shrubs. A.H. and A.W. Reed, Wellington.

Metcalfe, C.R. 1960. Anatomy of the Monocotyledons: I. Gramineae. Oxford University Press, London.

Moench, C. 1802. Supplementum ad Methodum Plantas: a staminum situ describendi. Marburgi Cattorum, in Officina nova Libraria Academiae.

Molloy, B.P.J. 1971. Possibilities and problems for nature conservation in a closely settled area. Proceedings of the New Zealand Ecological Society, 18:25-37.

Molloy, B.P.J., Burrows, C.J., Cox, J.E., Johnston, J.A., and Wardle, P. 1963. Distribution of subfossil forest remains, eastern South Island, New Zealand. New Zealand Journal of Botany, 1:68-77. https://doi.org/10.1080/0028825x.1963.10429322

Obata, J.K. 1967. Seed germination in native Hawaiian plants. Newsletter of the Hawaiian Botanical Society, 6:13-20.

Perry, G.L.W., Wilmshurst, J.M., McGlone, M.S., McWethy, D.B., and Whitlock, C. 2012. Explaining fire-driven landscape transformation during the Initial Burning Period of New Zealand's prehistory. Global Change Biology 18:1609-1621. https://doi.org/10.1111/j.1365-2486.2011.02631.x

Pocknall, D.T. 1978. Relative pollen representation in relation to vegetation composition, Westland, New Zealand. New Zealand Journal of Botany, 16:379-386. https://doi.org/10.1080/0028825x.1978.10425145

Pocknall, D.T. 1982. Modern pollen spectra from mountain localities, South Island, New Zealand. New Zealand Journal of Botany, 20:361-371. https://doi.org/10.1080/0028825x.1982.10428505

Pole, M. 2019. A survey of Pliocene to Mid-Quaternary leaf cuticle from the North Island, New Zealand. Palaeontologia Electronica 22.1.12A 1-32. https://doi.org/10.26879/862

Reichenbach, H.G.L. 1828. Conspectus regni vegetabilis per gradus naturales evoluti. C. Cnobloch, Leipzig.

Ritchie, N.A. 1982. The prehistoric role of the Cromwell Gorge, New Zealand. New Zealand Journal of Archaeology, 4:21-43.

Rogers, G.M., Walker, S., and Lee, W. 2005. The role of disturbance in dryland New Zealand: past and present. Science for Conservation, 258:1-122.

Scowcroft, P.G. 1982. Distribution and germination of mamane seeds. Pacific Southwest Forest and Range Experiment Station, Forest Service, U.S. Department of Agriculture; Research Note PSW, 356:1-4.

Seemann, B.C. 1865. Flora Vitiensis, 66, Reeve and Co., London.

Slaughter, R.J., Beasley, D.M.G., Lambie, B.S., Wilkins, G.T., and Schep, L.J. 2012. Poisonous plants in New Zealand: a review of those most commonly enquired about to the National Poisons Centre. The New Zealand Medical Journal, 125:87-118.

Specht, R.L. 1972. The Vegetation of South Australia. Government Printer, Adelaide.

Stevenson, G. B. 1935. The life history of the New Zealand species of the parasitic genus Korthalsella. Transactions of the Royal Society of New Zealand, 64:175-190.

Sultan, A. 2014. Systematics, biology and ecology of New Zealand's pygmy mistletoes (Korthalsella: Viscaceae). Unpublished PhD Thesis, Massey University, Massey.

Thompson, J. 1983. Redefinitions and nomenclatural changes within the Leptospermum suballiance of Myrtaceae. Telopea, 2:379-383. https://doi.org/10.7751/telopea19834403

Tieghem, P.É.L. van 1896. Korthalsella, genre noveau pour la famille des Loranthacées. Bulletin de la Société Botanique de France, 43:83-87.

van Riper III, C. 1980a. The phenology of the dryland Forest of Mauna Kea, Hawaii, and the impact of recent environmental perturbations. Biotropica, 12:282-291. https://doi.org/ $10.2307 / 2387700$

van Riper III, C. 1980b. Observations on the breeding of the palila Psittirostra bailleui of Hawaii. Ibis, 122:462-475. https://doi.org/10.1111/j.1474-919x.1980.tb00901.x 
Wagstaff, S.J. and Wardle, P. 1999. Whipcord hebes - systematics, distribution, ecology and evolution. New Zealand Journal of Botany, 37:17-39. https://doi.org/10.1080/0028825x.1999.9512609

Walker, S., King, N., Monks, A., Williams, S., Burrows, L., Cieraad, E., Meurk, C., Overton, J.M., Price, R., and Smale, M. 2009. Secondary woody vegetation patterns in New Zealand's South Island dryland zone. New Zealand Journal of Botany, 47:367-393. https://doi.org/10.1080/0028825x.2009.9672713

Walker, S., Lee, W.G., and Rogers, G.M. 2003. The woody vegetation of Central Otago, New Zealand. Science for Conservation, 226:5-99.

Walker, S., Lee, W.G., and Rogers, G.M. 2004a. The woody vegetation of Central Otago, New Zealand. New Zealand Journal of Botany, 42:589-612. https://doi.org/10.1080/0028825x.2004.9512914

Walker, S., Lee, W.G., and Rogers, G.M. 2004b. Pre-settlement woody vegetation of Central Otago, New Zealand. New Zealand Journal of Botany, 42:613-646. https://doi.org/10.1080/0028825x.2004.9512915

Wardle, P. 1991. Vegetation of New Zealand. Cambridge University Press, Cambridge.

Wardle, P. 2001a. Holocene forest fires in the upper Clutha district, Otago, New Zealand. New Zealand Journal of Botany, 39:523-542. https://doi.org/10.1080/0028825x.2001.9512755

Wardle, P.W. 2001b. Distribution of native forest in the upper Clutha district, Otago, New Zealand. New Zealand Journal of Botany, 39:435-446. https://doi.org/10.1080/0028825x.2001.9512747

Webb, J.A. 1993. A study of the seed ecology of two species of kowhai, Sophora microphylla and Sophora prostrata in Canterbury, New Zealand. Master of Science in Ecology in the University of Canterbury.

Wells, J.A. 1972. Ecology of Podocarpus hallii in Central Otago, New Zealand. New Zealand Journal of Botany, 10:399-426. https://doi.org/10.1080/0028825x.1972.10428614

Wilmshurst, J.M., McGlone, M.S., and Partridge, T.R. 1997. A late Holocene history of natural disturbance in lowland podocarp/hardwood forest, Hawke's Bay, New Zealand. New Zealand Journal of Botany, 35:79-96. https://doi.org/10.1080/0028825x.1997.10410671

Wilmshurst, J.M., McGlone, M.S., and Charman, D.J. 2002. Holocene vegetation and climate change in southern New Zealand: linkages between forest composition and quantitative surface moisture reconstructions from an ombrogenous bog. Journal of Quaternary Science, 17:653-666. https://doi.org/10.1002/jqs.689

Wilmshurst, J.M., Anderson, A.J., Higham, T.F.G., and Worthy, T.H. 2008. Dating the late prehistoric dispersal of Polynesians to New Zealand using the commensal Pacific rat. Proceedings of the National Academy of Sciences of the United States of America, 105:7676-7680. https://doi.org/10.1073/pnas.0801507105

Wood, J.R. 2008. Moa (Aves: Dinornithiformes) nesting material from the semiarid interior of South Island, New Zealand. Journal of the Royal Society of New Zealand, 38:115-129. https://doi.org/10.1080/03014220809510550

Wood, J.R. and Walker, S. 2008. Macrofossil evidence for pre-settlement vegetation of Central Otago's basin floors and gorges. New Zealand Journal of Botany, 45:239-255. https://doi.org/10.1080/00288250809509764

Wood, J.R. and Wilmshurst, J.M. 2013. Pollen analysis of coprolites reveals dietary details of heavy-footed moa (Pachyornis elephantopus) and coastal moa (Euryapteryx curtus) from Central Otago. New Zealand Journal of Ecology, 37:151-155.

Wood, J.R. and Wilmshurst, J.M. 2014. Late Quaternary terrestrial vertebrate coprolites from New Zealand. Quaternary Science Reviews, 98:33-44. https://doi.org/10.1016/j.quascirev.2014.05.020

Wood, J.R., Rawlence, N.J., Rogers, G.M., Austin, J.J., Worthy, T.H., and Cooper, A. 2008. Coprolite deposits reveal the diet and ecology of the extinct New Zealand megaherbivore moa (Aves, Dinornithiformes). Quaternary Science Reviews, 27:2593-2602. https://doi.org/10.1016/j.quascirev.2008.09.019

Wood, J.R., Wilmshurst, J.M., Worthy, T.H., and Cooper, A. 2012. First coprolite evidence for the diet of Anomalopteryx didiformis, an extinct forest ratite from New Zealand. New Zealand Journal of Ecology, 36:164-170. 
Wood, J.R., Wilmshurst, J.M. Richardson, S.J. Rawlence, N.J. Wagstaff, S.J. Worthy, T.H. and Cooper, A. 2013. Resolving lost herbivore community structure using coprolites of four sympatric moa species (Aves: Dinornithiformes). PNAS, 110:16910-16915. https://doi.org/10.1073/pnas.1307700110

Wood, J.R., Richardson, S.J., McGlone, M.S., and Wilmshurst, J.M. 2020. The diets of moa (Aves: Dinornithiformes). New Zealand Journal of Ecology, 44:3397. https://doi.org/10.20417/nzjecol.44.3

Wood, J.R., Vermeulen, M.J., Bolstridge, N., Briden, S., Cole, T.L., Rivera-Perez, J., Shepherd, L.D., Rawlence N.J., and Wilmshurst J.M. 2021. Mid-Holocene coprolites from southern New Zealand provide new insights into the diet and ecology of the extinct little bush moa (Anomalopteryx didiformis). Quaternary Science Reviews, 263:106992. https://doi.org/10.1016/j.quascirev.2021.106992

Wooller, M.J. 2002. Fossil grass cuticles from lacustrine sediments: a review of methods applicable to the analysis of tropical African lake cores. The Holocene, 12:97-105. https://doi.org/10.1191/0959683602hl524rr

Wooller, M.J., Street-Perrotta, F.A., and Agnew, A.D.Q. 2000. Late Quaternary fires and grassland palaeoecology of Mount Kenya, East Africa: evidence from charred grass cuticles in lake sediments. Palaeogeography, Palaeoclimatology, Palaeoecology, 164:207-230. https://doi.org/10.1016/s0031-0182(00)00187-5

Worthy, T.H. 1990. An analysis of the distribution and relative abundance of moa species (Aves: Dinornithiformes). New Zealand Journal of Zoology, 17:213-242. https://doi.org/10.1080/03014223.1990.10422598

Worthy, T.H. 1998. Quaternary fossil faunas of Otago, South Island, New Zealand. Journal of the Royal Society of New Zealand, 28:421-521. https://doi.org/10.1080/03014223.1998.9517573

Worthy, T.H. and Holdaway, R.N. 2002. The Lost World of the Moa: Prehistoric Life of New Zealand. Indiana University Press, Bloomington. 


\section{APPENDICES}

\section{APPENDIX 1.}

Location details of shelters. NZTM New Zealand Transverse Mercator. Biogeographic zones following Walker et al. (2004b). (Appendices available as zipped download at https://palaeo-electronica.org/content/2021/3503-vanished-ecosystem.)

\section{APPENDIX 2.}

Presence of each plant taxon (indicated by ' 1 ') in each shelter. The biogeographic zones of Walker et al. (2004b) are also indicated (missing ones are outside their study area). Note that three shelters had moa eggshell only, and one had coprolites only. Appendices available as zipped download at https://palaeo-electronica.org/content/2021/3503-vanished-ecosystem.)

\section{APPENDIX 3.}

Details of coprolites (Catalogue number, Shelter number, dimensions, cuticle content with catalogue number of corresponding slide). Appendices available as zipped download at https:// palaeo-electronica.org/content/2021/3503-vanished-ecosystem.) 